WIDER Working Paper 2014/059

\title{
Mozambique's industrialization
}

António Sousa Cruz, ${ }^{1}$ Dina Guambe, ${ }^{2}$ Constantino Pedro Marrengula, ${ }^{3}$ and Amosse Francisco Ubisse ${ }^{4}$

March 2014 
Abstract: After the Second World War, Mozambique went through a series of transformations, from an incipient industrializing colonial society to an independent country with a central planned economy, plus a regional and internal war, and finally from 1994 onwards, a multi-party democracy with a mix of market economy and a still strong public hand. Although growing at more than 7 per cent annually since 1992, the economy is mostly based on low-productivity agriculture. Manufacturing contributes with less than 15 per cent of its GDP, but mineral coal and natural gas tend to expand significantly. The economy faces the challenge to diversify, integrate and industrialize.

Keywords: manufacturing, investment, firms, policy, industrialization, Mozambique JEL classification: L1, L5, L6, O5

Acknowledgements: This paper is one of a series of studies on industrial development in Africa produced in collaboration between the Africa Growth Initiative at Brookings, the African Development Bank (AfDB), and UNU-WIDER under their joint project 'Learning to Compete' (L2C).

${ }^{1}$ Centre of Economic and Management Studies; ${ }^{2}$ Ministry of Planning and Development, ${ }^{3}$ Eduardo Mondlane University; 4National Institute of Statistics; corresponding author: antonioscruz@gmail.com

This study has been prepared within the UNU-WIDER project 'Learning to Compete: Accelerating Industrial Development in Africa', directed by John Page.

Copyright(C) UNU-WIDER 2014

ISSN 1798-7237ISBN 978-92-9230-780-6

Typescript prepared by Lisa Winkler at UNU-WIDER.

UNU-WIDER gratefully acknowledges the financial contributions to the research programme from the governments of Denmark, Finland, Sweden, and the United Kingdom.

The World Institute for Development Economics Research (WIDER) was established by the United Nations University (UNU) as its first research and training centre and started work in Helsinki, Finland in 1985. The Institute undertakes applied research and policy analysis on structural changes affecting the developing and transitional economies, provides a forum for the advocacy of policies leading to robust, equitable and environmentally sustainable growth, and promotes capacity strengthening and training in the field of economic, and social policy-making. Work is carried out by staff researchers and visiting scholars in Helsinki and through networks of collaborating scholars and institutions around the world.

UNU-WIDER, Katajanokanlaituri 6 B, 00160 Helsinki, Finland, wider.unu.edu

The views expressed in this publication are those of the author(s). Publication does not imply endorsement by the Institute or the United Nations University, nor by the programme/project sponsors, of any of the views expressed. 
The current Mozambican industrial development pattern, a mix of private sector initiative and a public sector licensing mechanism, replaced the post-independence public sector-led industrialization of the central planning countries tradition. The transition from a public-driven economy to a market-driven one, in the mid-1980s followed an international trend with the collapse of the socialist bloc countries and the end of the Cold War era.

Before its independence in 1975 from Portugal, Mozambique had a mixed industrialization pattern of a dual society. On one side, there was a growing colonial, urban and industrializing population, and on the other side, a local majority population dedicated to low-productive agriculture and other cheap manual activities like mining and public works. Although, the rules of a market economy applied, the public sector was heavily present, distorting labour relations. This national discrimination within an international market economy system partially explained the choice of a socialist economic system after independence.

Even though, Mozambique has undergone a series of social, political and economic transformations since the end of the Second World War, it still is a predominantly agricultural country, with twothirds of the population dedicated to agricultural, fishery and related production, utilizing lowproductivity traditional technology. The share of agriculture and related activities (plus livestock, fisheries and forestry) on the total gross domestic product (GDP) averages 29.6 per cent in the last 20 years (Figure 1). The manufacturing sector's value added had varied between 7.4 per cent and 17.2 per cent of the total GDP, with an average of 12.5 per cent in the same period (INE 2012). Various services account for the most of the share to the total GPD.

Currently, this country faces the challenge of choosing the most adequate strategy to transform the economic structure and achieve higher standards of living. Based on the previous industrial clusters around Maputo-Matola and Beira-Dondo, it has created an industrial free zone in Beluluane, special economic zones in Nacala and Beira, it has attracted mega-projects to produce aluminium and to extract and export natural gas in Pande and Temane, heavy sands in Moma and coal in Moatize and Benga. It is also developing light manufacturing in food processing and other agricultural products like tobacco and cotton. From an economic structure point of view, there still is no evidence that this trend represents a structural economic transformation from an agricultural country to an industrialized one with efficient services (Figure 1). Manufacturing value added is also losing weight on the total GDP after 2004 (INE 2012).

This paper discusses the evolution of industry in Mozambique since the colonial era in the first half of the twentieth century to date. Based on a literature review, it pays particular attention to four sectors: mining, manufacturing, electricity and water and the construction sector. This paper presents the introduction in Section 1, describes the evolution of industry in Section 2, presents the structure of the industrial sector in Section 3, the current industrial policy framework in Section 4 and concluding remarks in Section 5. 


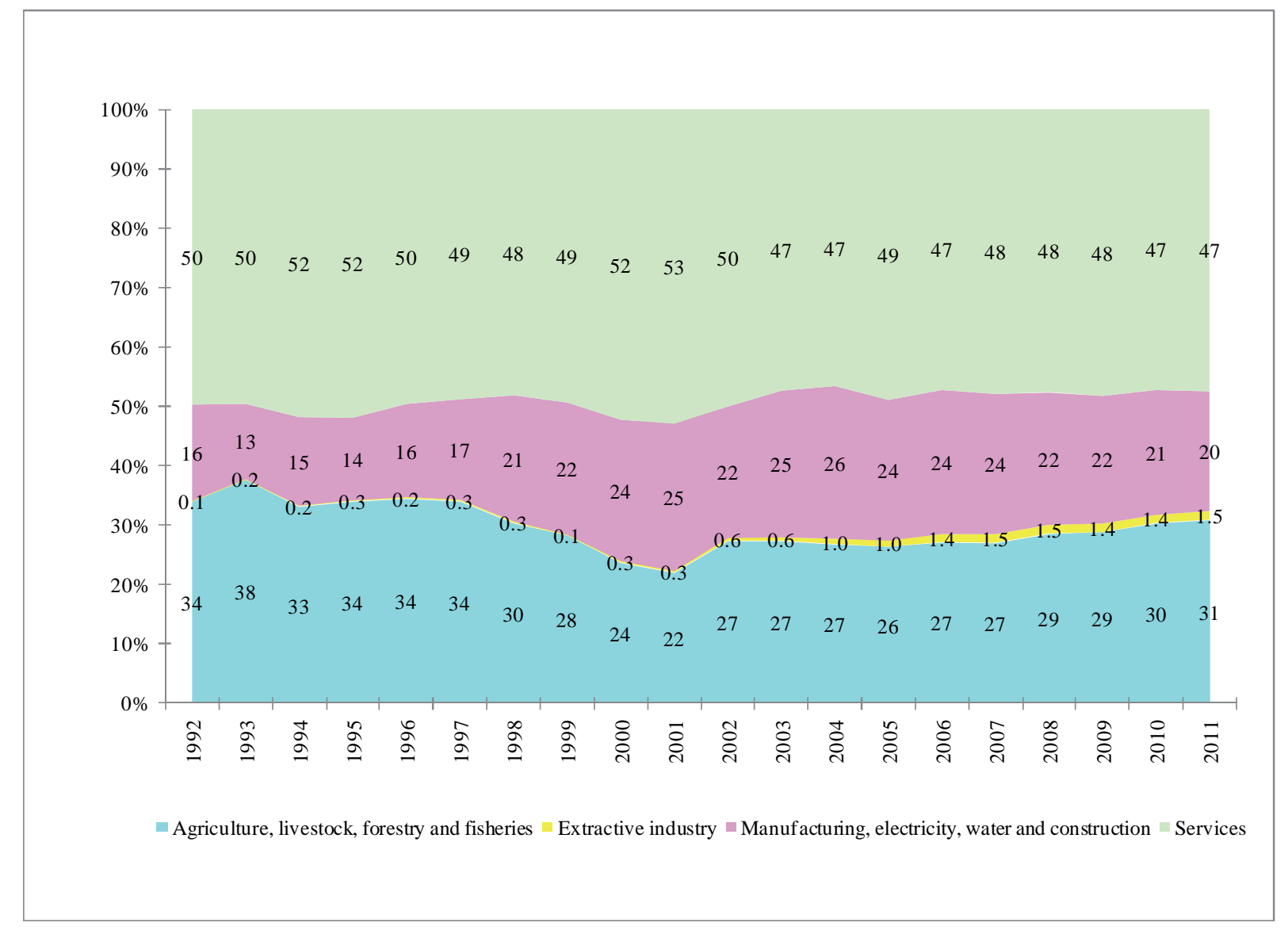

Note: The sectoral structure adds up to 100 per cent, separated from implicit financial sector margins and taxes on products, which is different from INE's sectoral shares.

Source: authors, based on INE (2012).

\section{The evolution of industry}

\subsection{After the First and during the Second World War: 1920-45}

Before the First World War, the manufacturing sector in Mozambique was producing mainly semiprocessed agricultural products for exports, like sugar cane, sisal, tea, copra and cotton. In the 1920s, Portugal, the colonial power, adopted a more aggressive approach towards Mozambique's industrialization, expanding the range of manufactured new agricultural products, including wood and palm oil. At the same time, following deliberate efforts to expand the population of Portuguese settlers, new inward-oriented industries began operation, including cement, corn flour, cigarettes, soap, mineral waters and ice. Table 1 below reports Mozambique's industrial production in 1928.

The production of minerals, mainly coal, initiated in 1923, in Moatize, Tete province, the current Mozambique mineral hub. At the end of the 1920s, the salt industry in Quelimane and Ilha of Mozambique, ship maintenance, beer and juice industries in Lourenço Marques (today Maputo) 
started operations. Cotton production in Mozambique provided cheap raw material for the textile industry in mainland Portugal. Low cotton prices were achieved through peasants' forced labour in the colony (Wuyts 1980; Ministério das Colónias em Moçambique 1928; Mondlane 1976).

Table 1: Industrial production, 1928

\begin{tabular}{lr}
\hline Products & Quantities \\
\hline Cement & 14,049 ton \\
Corn flour & 2,718 ton \\
Soap & 388 ton \\
Ice & 2,960 ton \\
Beer & 22,780 lit \\
Mineral waters & 129,280 lit \\
Cigarettes & $263,708,860$ unities \\
\hline
\end{tabular}

Source: UEM (1983a).

During the Second World War, due to unsafe ocean routes and the deviation of international financial resources for the war, the Mozambican economy suffered a decline in exports. These had increased about seven times between 1927 and 1937. Afterwards, until 1944, Mozambican exports declined to levels below the 1927 exports (Leite 1989). Due to war restrictions and the rise in the number of settlers in the colony, industry output tended to rise after 1945. The manufacturing of soap, tobacco, beer, cement and textiles expanded (Brum 1976).

Excluding the great depression phase, industrial production maintained a steady growth between the 1920s and 1960s (UEM 1983b). This trend was reinforced and sustained by the general positive outlook of the world economy, after the great depression and the Second World War.

\subsection{Post-Second World War: 1945-61}

Mozambique's industrial development from 1945 to 1960s can be better understood within the colonial rules that Portugal adopted to govern her economic relationship within the colonial territories in Africa. Within the Portuguese development strategy, Mozambique had to be: (i) the source of raw material for Portuguese industries; (ii) the supplier of cheap labour; (iii) the export market of Portuguese manufacturing goods, and (iv) the labour market for the unemployed Portuguese.

These elements shaped colonial government economic policies, and in particular regarding the industrialization. While it promoted the production of agricultural goods such as cotton, sisal, cashew nut and palm oil, it also imposed restrictions for the local production of manufactured goods that posed immediate threat to Portuguese exports to Mozambique. Due to the high rate of unemployment in mainland Portugal, it encouraged the establishment of Portuguese settlers around the most productive areas in Mozambique and adopted deliberate supportive measures to empower them.

The Portuguese government replaced the colonial pact with foment plans (Leite 1989). The colonial pact represented the transfer of cheap agricultural products and raw materials from the colony to the mainland. With the implementation of the first foment plan in 1953, the colonial economy should become more integrated, with a larger proportion of the financing package coming from within the 
colony, an increase in infrastructure investment to support the economic activity and the industrial park expansion (Wuyts 1983).

The number of enterprises increased from 150 in 1947, two years after the Second World War, to 1,025 in 1961 (Table 2). Capita stock expanded from 796 million escudos in 1947 to 4,610 million escudos in 1961. This implied a steady production expansion. From 1955 to 1961, the production index, in fact, doubled (Table 3).

Table 2: Growth of manufacturing sector, 1947-61

\begin{tabular}{lrrrrr}
\hline Year & 1947 & 1954 & 1956 & 1958 & 1961 \\
\hline Number of enterprises & 150 & 157 & 690 & 913 & 1,025 \\
Capital stock (million escudos) $^{\star}$ & 796 & 1,146 & 2,134 & 2,954 & 4,610 \\
\hline
\end{tabular}

Note: *Portuguese currency

Source: UEM (1983b).

Table 3: Evolution of production, 1955-61

\begin{tabular}{l|llll}
\hline Year & 1955 & 1957 & 1959 & 1961 \\
\hline Production index $(1955=100)$ & 100 & 127.9 & 159.4 & 223.5 \\
\hline
\end{tabular}

Source: UEM (1983b).

The number of Portuguese settlers in Mozambique increased significantly following the first national development plan introduced in the 1950s, 'Plano de Fomento 1953-58'. The manufacturing output for the domestic market expanded with the creation of new products, like chocolate and baked goods in 1947, wheat milling in 1952, cotton articles and clothing in 1954, animal feed and footwear in 1955, paper, furniture, gas, metal works, machine repair and transport vehicles in 1956 and glassware in 1958 (Wield 1977). At this stage, occurred an import substitution in order to satisfy the increasing demand from the settlers' community. Investment in machinery and equipment expanded from 1956 to 1960.

From the 1940s onwards, although Mozambique remained focused on export markets, the share of industrial production for the domestic market in total output increased from 28 per cent in 1942 to 46 per cent in 1960, implying the emergence of a structural shift towards greater reliance on domestic market (Table 4). This was the result of increased urbanization and an expansion of public investment, following the massive inflow of Portuguese settlers and the adoption of the first development plan in the 1950s.

Table 4: Proportion of industrial production per destination market, 1942-60 (in \%)

\begin{tabular}{lrrr}
\hline & 1942 & 1955 & 1960 \\
\hline Industrial production for external market & 72 & 60 & 54 \\
Industrial production for internal market & 28 & 40 & 46
\end{tabular}

Source: UEM (1983b).

Besides being successful in building a relatively diversified industrial base, by Sub-Saharan Africa (SSA) standards at the time, the colonial government managed to support the emergence of a 
selected number of heavy industries such as metal work, vehicle maintenance, electricity, cement, gas and water (Table 5).

Table 5: Investment flow in the manufacturing sector, 1956-61 (thousand escudos)

\begin{tabular}{llrr}
\hline Sector/year & & 1956 & 1961 \\
\hline Textiles & Ginning, processing and preparation of textiles fibres & 445,872 & 824,471 \\
& Spinning, weaving and finishing & 140,653 & 205,192 \\
& Footwear, apparel and textiles in work & 370 & 8,931 \\
Food industry & Sugar refinery & 376,344 & 808,120 \\
& Grinding, hulling grain & 198,648 & 363,222 \\
& Various & 118,398 & 158,122 \\
& Refined oils and fats & 134,015 & 158,112 \\
Wood & & 197,143 & 347,919 \\
Cement & & 192,014 & 379,433 \\
Petrol refinery & & - & 218,403 \\
Beverages & & 46,977 & 201,698 \\
Vehicle maintenance & 28,641 & 147,209 \\
Metal industry & & 49,265 & 114,059 \\
Electricity, gas and water & 330,306 & 581,877 \\
\hline
\end{tabular}

Source: UEM (1983b).

The national independence movements throughout Africa in the late 1950s and early 1960s put pressure on Portugal to reform its relations with the colonies. In 1961, the Angolan Liberation Popular Movement started its armed struggle in that colony; the Portuguese government approved the Portuguese economic space integration law, created the escudo zone and approved the forced labour abolition law (Presidência do Conselho 1961; Wuyts 1983:2; Wuyts 1980:11, 21). These reforms and the implementation of foment plans contributed for the industrial acceleration in the following period.

\subsection{Colonial industrial acceleration: 1961-74}

The Mozambique Liberation Front (Frelimo) was created in 1962 and started waging a liberation war in 1964.In the global scene there was increased pressure on Portugal to free its colonies in Africa, including Mozambique. To counteract the mounting pressure, Portugal adopted a more interventionist economic policy with a view to convince the world that its African colonies were natural extensions of Portugal, expanding investment and the inflow of Portuguese settlers.

During this period, the colonial government implemented two additional development plans: 'Plano de Fomento II (1959-64)' and 'Plano de Fomento III (1968-73)', with an intermediate plan for 196567. A fourth plan was designed to be implemented from 1974 onwards. The objectives of both plans, II and III, differ in terms of emphasis in selected aspects. But the ultimate targets remained similar.

The second development plan ('Plano de Fomento II') stated the following objectives: (i) reinforce the settlement strategy in Mozambique, bringing in additional incentives programmes to grow tobacco, tea and rice along the most productive Mozambican river basins, Zambezi and Limpopo; (ii) develop communication and transport sectors; (iii) increase exploitation of agricultural, forests, 
livestock and hydroelectric resources; (iv) conduct land studies, including geological surveys. In 1961 Portugal decided to invest 635 million escudos, of which 1.1 per cent was destined to do geological and mining studies, 12.28 per cent for agriculture, forest and livestock and 8.35 per cent for industrialization (UEM 1983b).

The third development plan ('Plano de Fomento III') brought more emphasis on boosting local production, particularly on agricultural products, such as tea and rice along the Limpopo and Zambezi river basin. It deliberately followed an import substitution strategy. Specific objectives included the need to: (i) respond to the increased demand of consumption goods by the local population, (ii) support the development of new opportunities of investment for the Portuguese settlers, (iii) build a market for outdated technologies and equipment from Portugal which were in the process of being replaced by modern technologies and equipment; (iv) improve the image of the colonial government, reducing, as a result, the pressure for the country's independence. For the export sector, the third development plan gave emphasis to the need to: (i) reduce the relative costs of transport and (ii) ensure the conservation and maintenance of goods (Castel-Branco 2002).

Following a trend that, in fact, initiated in the 1920 s, the colonial government sustained efforts for industrialization can be deemed as a success history. In 1964, industrial production for the domestic market became larger than the industrial production for the external market (Figure 2; Leite 1989: 842).

In the 1960s, the financial system in Mozambique expanded. Portuguese, international and Mozambican capital funded various banks, financial and savings institutions (Wuyts 1983: 8-9). Industrial development benefited from this increase in capital availability. Industrial businessman strengthened the equipment production, creating the sector of laminated iron and steel, the sector of construction and the assembly of railways transportation materials and a petroleum refinery (Brum 1976).

Figure 2: Manufacturing production per destination market

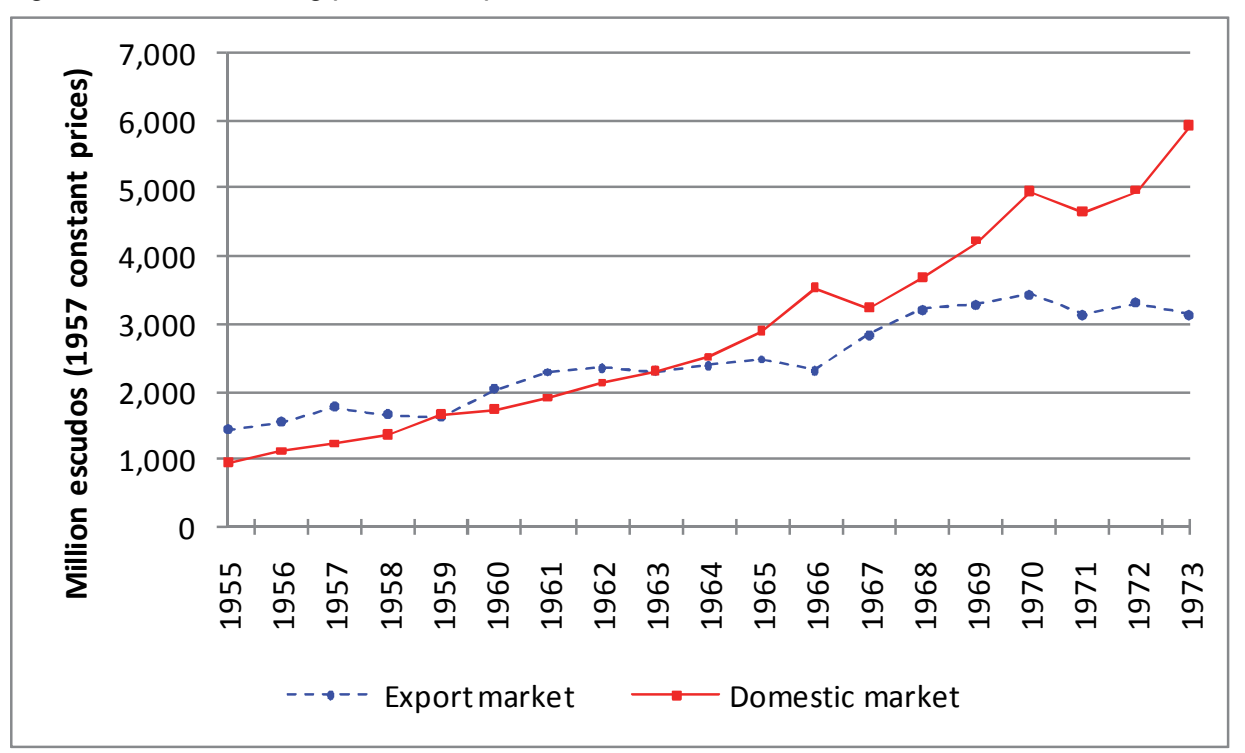

Source: authors, based on Leite (1989). 
The machinery branch value of production increased its proportion on the total manufacturing output from 1956 to 1970 (Figure 3). This expansion was accompanied by an increase in imports of complementary machinery and equipment as a percentage of total imports, from 18 per cent in 1965 to 27 per cent in 1970 (DSPIE 1962; 1973). The increase in spending on imports was being compensated by the increase in revenues from cashew, sugar and services exports.

However, by the end of the 1960s, the external financing became constrained by a lower availability of reserves in gold and foreign currency and the strong debt with Portugal (Wuyts 1983). Consequently, the import substitution strategy was strengthened. The production of canned food, radios, shoes and razor machines was developed in the 1970s (Brum 1976).

The dominant industries included: manufacturers of agricultural crops, including cotton, sugar, tea, timber, flowers, tobacco, as well as, producers of refined oil, soap, fatty acids, cashew nuts, cement. In 1973 the textile, cashew nut and sugar industry's share in total exports was more than 50 per cent. Together they made more than 85 per cent of manufactured exports (Castel-Branco 2002).

Although, the manufacturing branches were becoming more and more integrated in the period 1961-74, there were shortcomings that could threat the future development: it was a colonial society, where most of the specialized positions in the industry and in the rest of the economy were occupied by settlers; parts of the industrial machinery and equipment were second-hand imported.

Following the 1973 international oil prices crisis, the 25 April 1974 military coup d'état in Portugal and the negotiations between the Portuguese government and Frelimo on 7 September 1974, the economy in Mozambique entered into a transitional period until the independence in 25 June 1975. This transition affected the economy negatively.

Figure 3: Machinery production, 1956-73

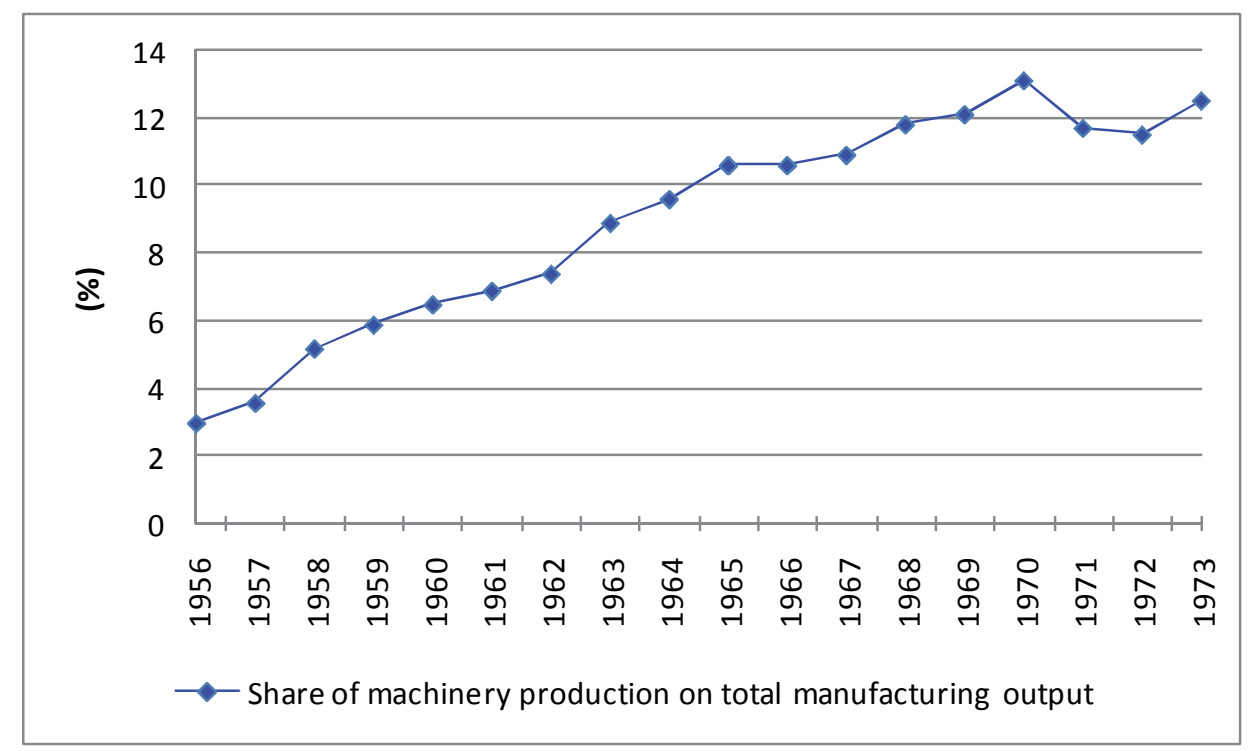

Note: Machinery, branch 38, 1968 United Nations Industrial Classification at 2-digit level. Source: Cruz (1994). 


\subsection{Post-independence industrial development (1975-86): central planning economy}

In 1975, Mozambique was considered the 8th largest industrial producer in Sub- Saharan Africa (RPED 1999). Manufacturing value added was above 10 per cent of the GDP. The manufacturing sector had diversified within a context of high effective protection. Mozambique also had one of the largest hydro power plants in Africa: The Cahora Bassa Dam.

It was under this scenario that the Mozambican government adopted a series of nationalist and socialist policies in the first years, after the independence in 1975. Besides occupying top government positions, Mozambicans also occupied progressively most of the medium positions in public institutions and private enterprises. There was a massive exodus of Portuguese settlers out of Mozambique. They were replaced by Mozambicans and expatriates. The latter ones were called 'cooperantes' from the socialist countries, African and Western countries with a similar left ideology. The new government of Mozambique's initial response to the challenges of industrialization is reported in a series of policy measures adopted during the third and fourth Frelimo Congresses (Frelimo 1977; 1983).

The third Frelimo congress targeted the satisfaction of basic needs as the main objective of economic policy, placing industry as the main driver for structural transformation of the Mozambican economy. Regarding the industrial sector, the congress resolution stated the following specific objectives:

- Ensure the satisfaction of people's needs in food, clothes, footwear, fuels, energy, hygienic products and household goods;

- Provision of raw material, fuels and means of production for all sectors, particularly for agriculture;

- Ensure value addition for agricultural and marine products;

- Contribute for the equilibrium of balance of payment.

Other objectives included:

- Improvement of co-ordination among different branch of industry;

- Ensure inter-sectoral linkages, in particular with agriculture;

- Implement geological surveys to map the existing country resources;

- Build a pool of technical manpower;

- Introduce new and improved management methods in production unities;

- Prepare a ten-year industrialization plan;

- Set up appropriate bureaucratic structures for steering industrialization, following a centrally planned model;

- Intervene on abandoned private companies, turning them into state-owned;

- Introduce norm and quality control standards in order to satisfy the requirements of domestic and external markets.

In line with the third Congress decisions, in 1978/1979, the government allocated massive investment on agriculture and industry, since both were defined as priority sectors for satisfying people's needs. Agriculture received almost the double of the amount invested in industry. The manufacturing sector received its highest investment flow in 1983 (Table 6). 
Table 6: State budget investment (in million Meticais)*

\begin{tabular}{lrrrrr}
\hline & \multicolumn{1}{c}{$1978 / 79$} & \multicolumn{1}{c}{1980} & \multicolumn{1}{c}{1981} & \multicolumn{1}{c}{1982} & \multicolumn{1}{c}{1983} \\
\hline Agriculture & $1,095.0$ & $2,271.0$ & $4,181.0$ & $4,826.0$ & $4,345.0$ \\
Industry and energy & 561.0 & $1,227.0$ & $3,349.0$ & $3,493.0$ & $4,332.0$ \\
Construction & $5,457.0$ & $3,346.0$ & $3,270.0$ & $2,424.0$ & $4,241.0$ \\
Transport and communication & 177.0 & 155.0 & 345.0 & 468.0 & $1,203.0$ \\
Several & - & $1,028.0$ & 682.0 & $1,080.0$ & 674.0 \\
Economic sectors & $7,290.0$ & $8,027.0$ & $11,827.0$ & $12,291.0$ & $14,795.0$ \\
\hline
\end{tabular}

Note: * Mozambican currency.

Source: DNE-CNP (1985).

Following the inflow of fresh human and financial resources, the economy stopped deterioration, reaching the highest post-independence growth rate in 1981 (Table 6 and Table 7).

Table 7: Global social product, constant prices of 1980 (billion Meticais)

\begin{tabular}{lrrrrrrr}
\hline & \multicolumn{1}{r}{1975} & 1977 & 1980 & 1981 & 1982 & 1983 & \multicolumn{1}{c}{1984} \\
\hline Agriculture & 26,1 & 30,6 & 33,4 & 33,3 & 32,5 & 25,0 & 25,7 \\
Industry & 26,4 & 27,8 & 30,7 & 31,6 & 27,2 & 22,5 & 15,5 \\
Construction & 4,0 & 3,6 & 4,8 & 4,5 & 4,7 & 4,7 & 4,3 \\
Transport & 9,1 & 7,8 & 8,1 & 9,0 & 8,4 & 6,7 & 5,3 \\
Trading and others & 5,5 & 5,2 & 5,2 & 5,3 & 5,1 & 5,0 & 4,8 \\
Total GSP & 71,1 & 75,0 & 82,2 & 83,7 & 77,9 & 63,9 & 55,6 \\
\hline
\end{tabular}

Source: DNE-CNP (1985).

The year 1981 is in fact the best reference year when assessing the country's post-independence economic performance. The global social product (GSP), an indicator of the material product of a country, increased from 71.1 billion Meticais in 1975 to 83.7 billion in 1981, at 1980 constant prices (Table 7). The agriculture and manufacturing sector shares in GSP were 40 per cent and 38 per cent, respectively (Figure 4).

Figure 4: Contribution of economic sectors in gross social product, 1981

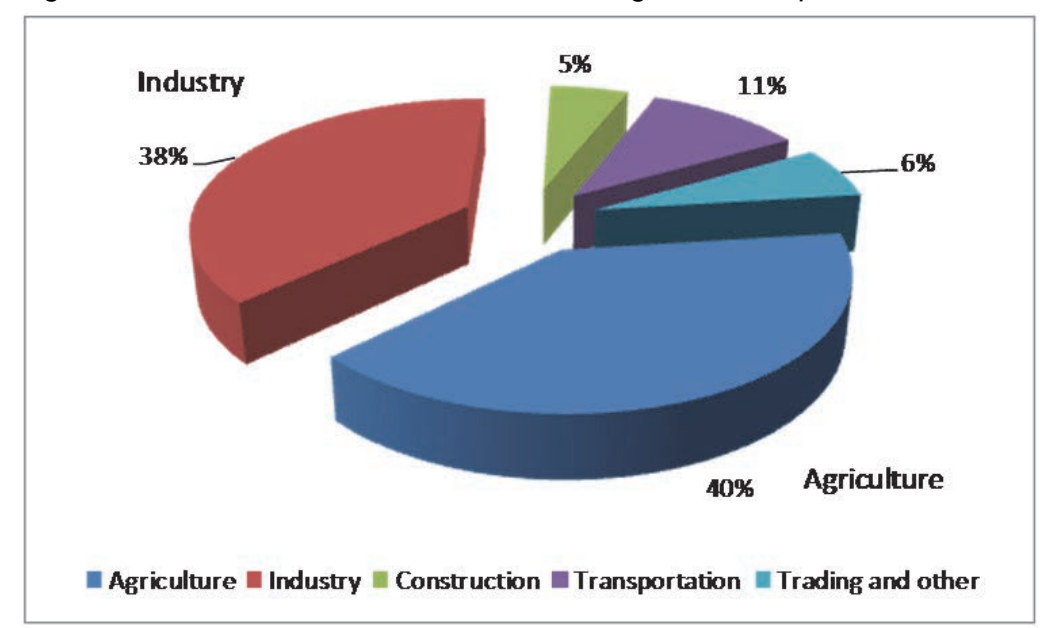

Source: authors, based on DNE-CNP (1985). 
Major contributors to the manufacturing sector growth included: petrol, rubber, metal works, textiles, oil, soaps and fisheries.

The gains from the third Frelimo congress were, however, short-lived. The country suffered a major drought in 1983. It failed to mobilize the much-needed donor funds for sustaining its ten year (198090) development plan. The war was spreading throughout the country, besides increasing ruralurban exodus and informality.

The fourth Frelimo congress, in 1983, took place amid increased social tension and discontent. The congress's resolution stressed the need to ensure the provision of basic goods, through investment in agriculture and industry as the main driver for structural transformation. It called for greater emphasis on import substitution and the development of small and medium enterprises. To open the space for other actors, it introduced the first generation of liberalization measures in Mozambique, removing government control over prices of selected goods, including vegetables in 1984.

It also encouraged the government to retreat from retail business. Through a special credit line, the government further tried to stimulate the emergence of private initiatives among potential indigenous entrepreneurs besides adopting the first set of steps towards the attraction of foreign private capital investment. The main objective was to ensure additional investment for import substitution.

The fourth congress's policy objective for the manufacturing sector aimed at 'increasing industrial production to $12-15$ per cent in 1985, compared to 1980, especially in textiles, fisheries, metal works, mechanic constructions, metallurgic and ship maintenance'. Particular focus was set on maximizing capacity utilization; the use of local resources, ensuring efficiency and cost minimization.

The set of measures introduced in 1983 had the merit of bringing greater focus on domestic constraints for industrial growth, including some form of economic freedom. It was the first time since independence that the ruling party officially considered private investors a relevant partner for economic growth and the country development. As it happened with the previous postindependence economic policy measures, the decisions of the fourth congress were, however, insufficient to put the country on a sustained growth path. The war continued its destructive toll.

The industrial slowdown was particular costly. While until 1981 it appeared that the country had found its way out from economic collapse, around the mid-1980s, the situation worsened (Figure 5). The strong state economic intervention turned out to be unsustainable, leading to costly distortions in the allocation of resources and badly disrupted the private sector production. The agricultural and the overall rural sector production suffered, reducing therefore the supply of raw material to the whole industry and the domestic demand for final industrial goods. By the second quarter of the 1980s the productive sector was operating at 10 per cent to 30 per cent of its capacity. Average labour productivity had declined by more than 60 per cent. The agricultural sector was reduced to subsistence level. Exports, in particular tea, cashew nuts, cotton and sugar declined to one-third of pre-independence levels (Castel-Branco 2002). 
Figure 5: Gross domestic product, 1965-2012

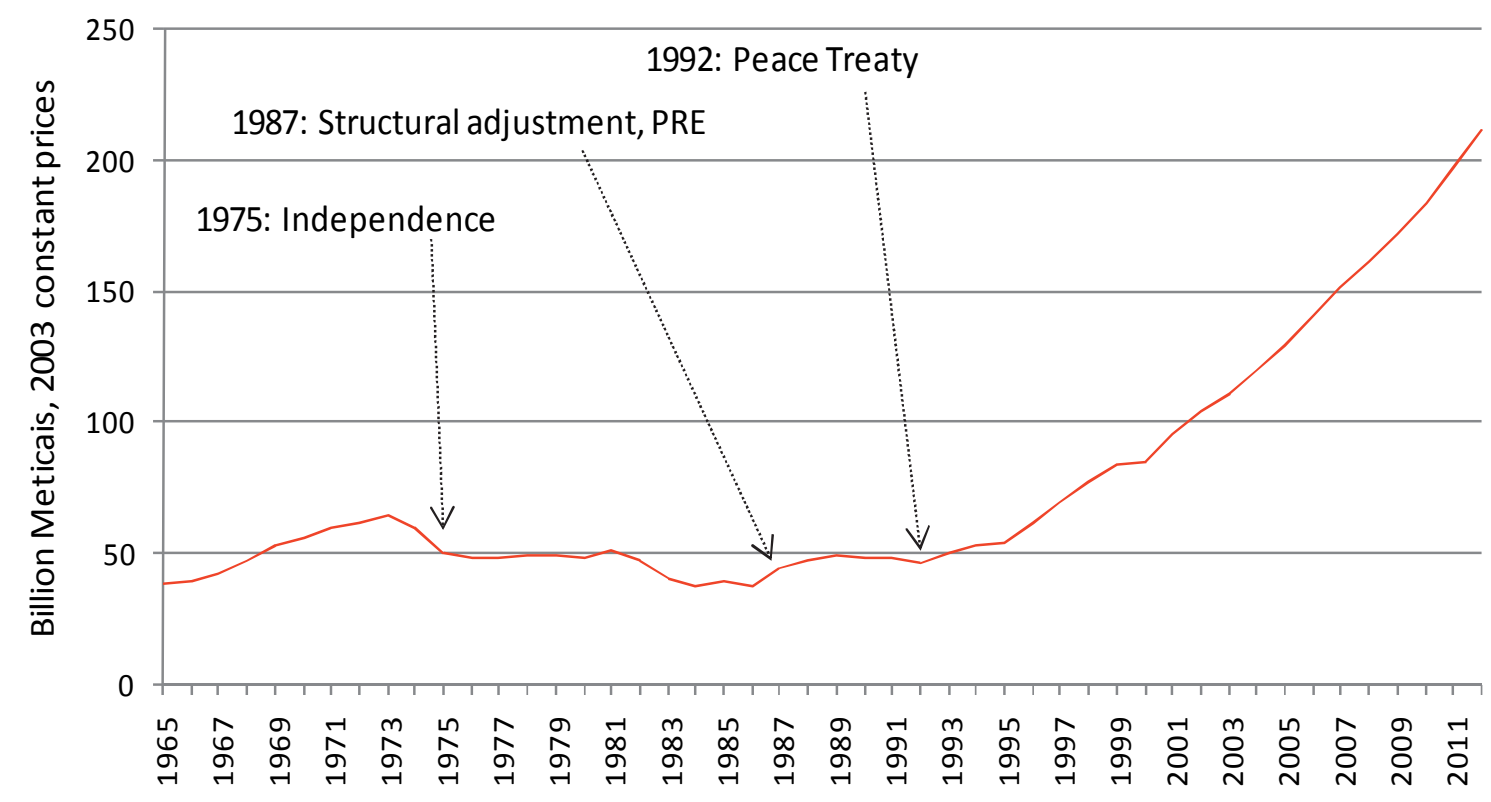

Source: authors, based on Sulemane (2002) and INE (2012).

The combined effects of reduced supply of raw materials, limited demand of final goods and the failure of the export-oriented agricultural sector left the country near a collapse state. The war and natural disasters added to the problem through sabotage of infrastructure and disruption of the road network.

By the year 1986, despite being a monopoly, capacity utilization at the cement industry, one of main drivers of industrial development was below 50 per cent. The civil and heavy construction industries were stagnant, surviving on the base of state subsidies, while holding a significant proportion of redundant labour force. The colonial era logistics, learning expertise, as well as market intelligence broke down, after the massive exodus of skilled labour that followed independence and the destabilization and civil war. These factors and the collapse of the centrally planned economy, led to a declining economic performance, reaching in 1986 its lowest GDP level since the late 1960s.

Within a long-term perspective, 1974 marked a break in the society and the economy. Mozambique became a distinct country with the independence in the following year. Comparisons between preand post-independence should take this into consideration.

The structural break in the economy and in the manufacturing sector in particular, occurred between 1974 and 1992 (Figure 5 and Figure 6). This was a period of declining and stagnating output. The first phase occurred between 1974-75 and 1986. From 1975 onwards, the new Mozambican government had implemented a series of national and socialist policies, with the public sector as the dominant economic actor, reforming state institutions and electing the heavy industry as the main growth driver. As this economic system failed and the global production tended downwards, the 
Mozambican government gradually shifted towards the market economy system, as well as exchanged its international economic relations focus from the socialist countries to the BrettonWoods institutions, including Western countries in 1983-84. In 1986 Mozambique achieved the lowest output level since the 1960s, as the destabilization and civil war also intensified.

Figure 6: Gross domestic product per capita, 1965-2012

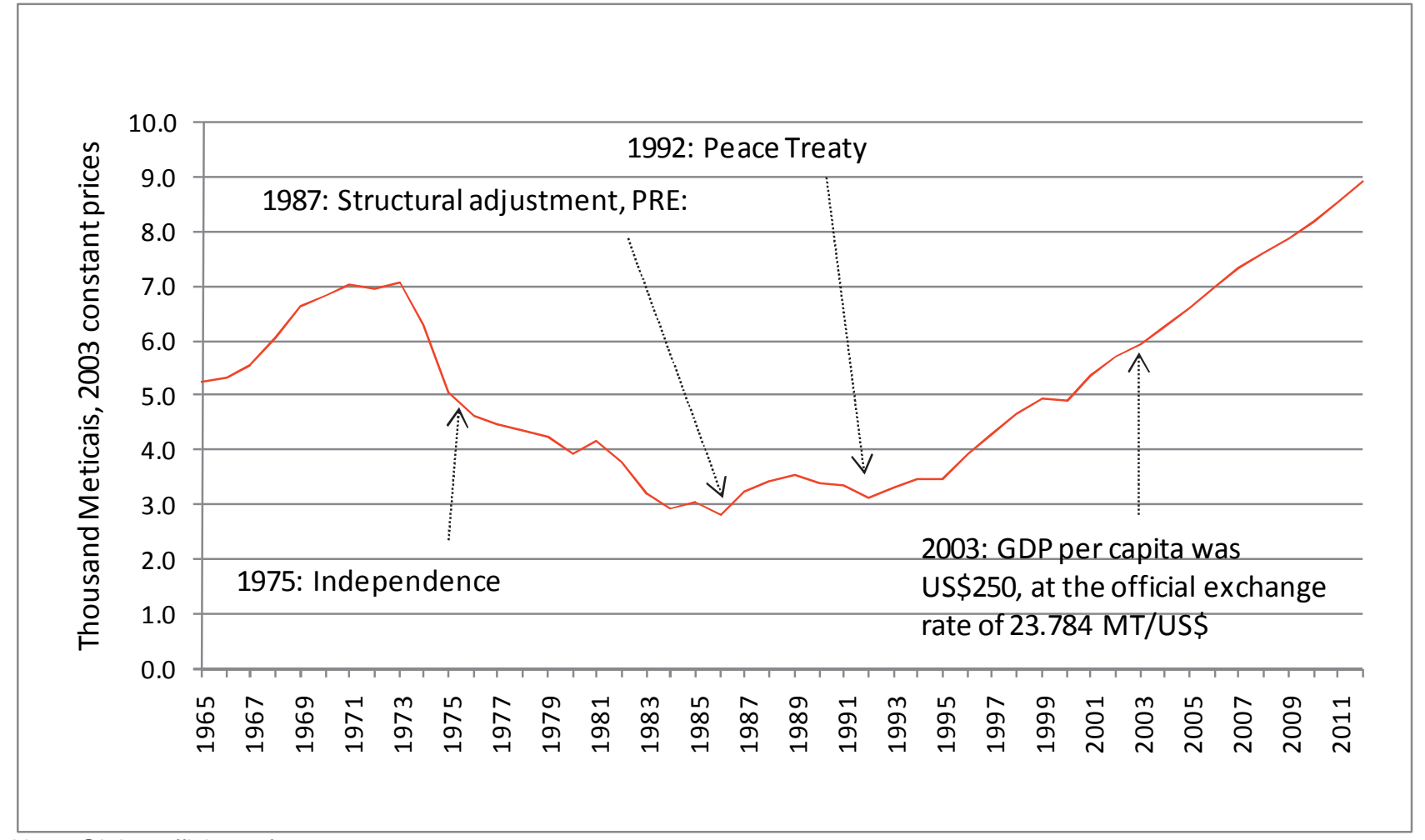

Note: Gini coefficient of 0.41 .

Source: authors, based on INE (2008, 2010; 2012), Sulemane (2002) and MPD (2010).

\subsection{Transitional industrial development (1987-96): Towards a market-oriented economy}

Mozambique introduced the Economic Rehabilitation Program (PRE) in 1987 and a more marketfriendly constitution law in 1990. In order to account for the social dimension within the structural adjustment programme, the government adopted the Social and Economic Rehabilitation Program (PRES) a few years after 1987.

In 1992, the government and Renamo (Mozambican National Resistance) signed the peace agreement, marking the end to a destructive 16 year destabilization and civil war, as well as the end of the structural break of the economy. This removed the most important barrier to industrial development and allowed the country to access the much needed donor funds. Government intervention was no longer taken as the main driver for industrialization and economic development. Instead, emphasis was on developing the private sector as the main source for growth and the market forces as the appropriate mechanism to guide resource allocation. From 1992 onwards, the country followed a long period of economic expansion (Figure 5). 
For the domestic industries, the PRE liberalization and privatization has implied not only the change of assets' ownership, but also: (i) losing a safe market from the government as well as special preference from the now privatized financial sector; (ii) exposure to global competition; (iii) opportunities to explore the more competitive market segment; (iv) opportunities for partnership with foreign private capital and (v) opportunities for technological upgrading and transfers. Table 8 reports a number of policy interventions that resulted from the PRE.

Table 8: Policy interventions under the economic rehabilitation programme

\begin{tabular}{|c|c|c|c|c|}
\hline & Policy & ntion & Evaluatior & \\
\hline & Instrument & Purpose of policy & Success & Failure \\
\hline & & & Economic growth & \\
\hline & & & High technical efficient & However, the \\
\hline & & & & efficiency was \\
\hline & & & Better access to capital, & not enough to \\
\hline & & & modern production & allow firms to \\
\hline & & & techniques and knowledge & compete in world \\
\hline & & Stop the economic & & market \\
\hline & I iboralizetion & deterioration & & Textiles sector \\
\hline & Liverallzalion & Establish market- & Improved access to & loss clothing \\
\hline & & oriented economy & strategic raw materials & markets in \\
\hline & & & & Eastern Europe \\
\hline & & & Increase in demand & \\
\hline & & & Appearance of new & \\
\hline & & & manufacturing firms owned & \\
\hline & & & by foreigners & \\
\hline Policy reforms & & & & Non-exporters \\
\hline PRE \& PRES & & & & did not \\
\hline & & & Growth rate of sales and job & comparatively \\
\hline & & & creation & perform better in \\
\hline & & & & $\begin{array}{l}\text { sales and } \\
\text { employment }\end{array}$ \\
\hline & & & Increase capacity utilization & Workers less \\
\hline & & Stop the economic & Decource chift towards & \\
\hline & Privatization & deterioration; & $\begin{array}{l}\text { Resource shitt towards } \\
\text { efficient firms }\end{array}$ & \\
\hline & & Establish market- & Increase in private & \\
\hline & & & investment mainly in capital & \\
\hline & & & equipment. & \\
\hline & & & Increase in manufacturing & \\
\hline & & & productivity & \\
\hline & & & High labour and capital & \\
\hline & & & productivity of privatized & \\
\hline & & & firms & \\
\hline
\end{tabular}

Source: authors, based on Castel-Branco (2002). 
When PRE was implemented, the industry was in a collapsing state. It had stopped receiving investment since the first post-independence inflow of resources that followed the third Frelimo Congresss. Technology was outdated and companies could not have an easy access to spare parts. Machine break down was a frequent phenomenon. The introduction of liberalization measures and the inflow of the much needed donor funds were instrumental for changing the sector fortune. In 1992-93, after the peace agreement and by coincidence rainfall patterns normalized, macroeconomic, trade and financial reforms began to bear fruit. The manufacturing sector resumed a positive growth trend in 1995 (Figure 7). Real growth rates per annum averaged 16.7 per cent in 1995-97. Macroeconomic stability and the liberalization measures had a substantial impact on it.

Figure 7: GDP and manufacturing growth rates, 1992-2011

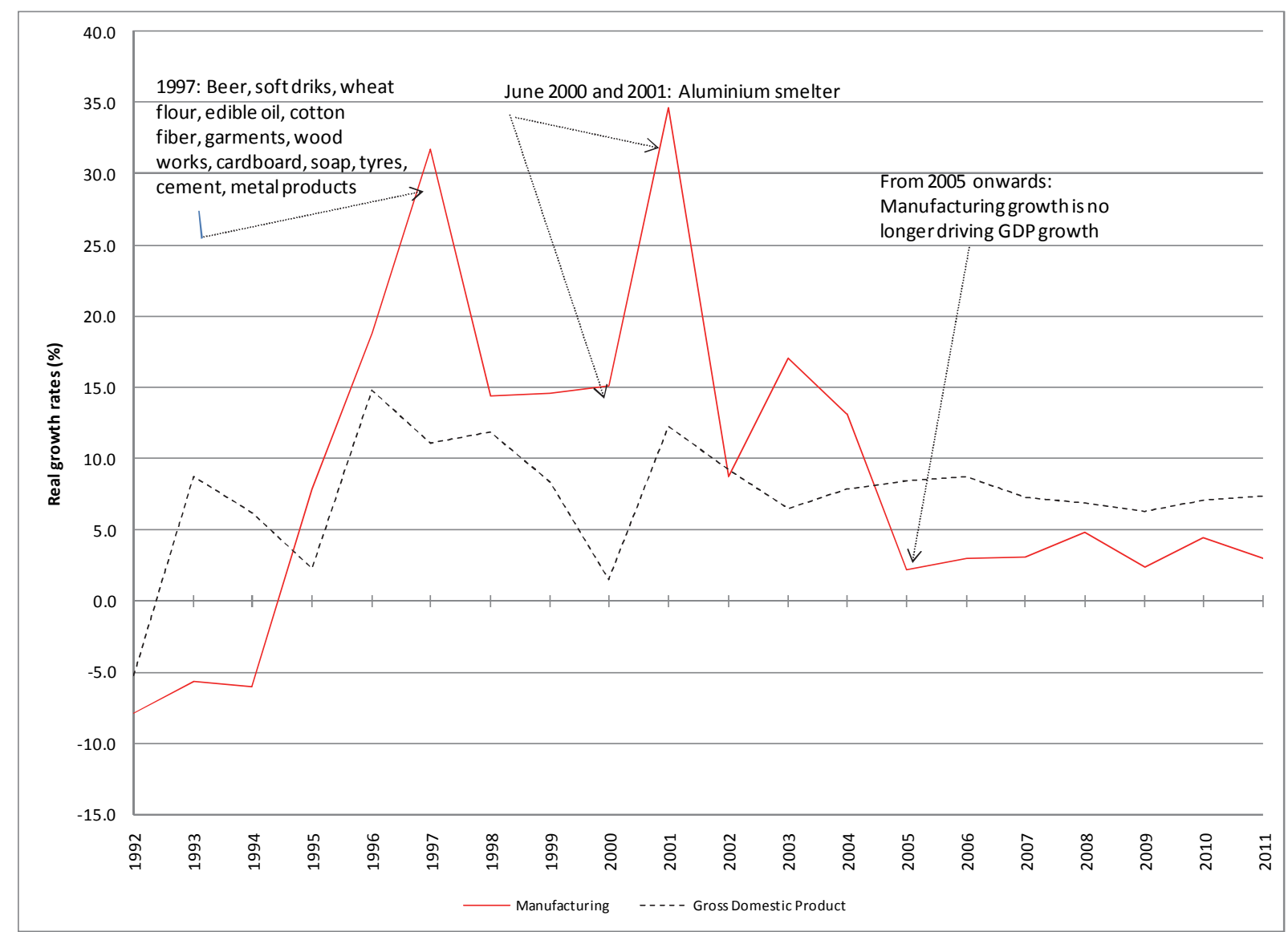

Source: authors, based on INE (2012).

Aiming at assessing the growth of the manufacturing sector, the World Bank collected information on the recent growth episodes of firms (RPED 1999). The study reported that sales among the sample surveyed grew at an average annual rate of 30 per cent from 1992 through 1997. The growth in employment was, however, limited, suggesting that the reported growth was more a result of increased capacity utilization, rather than a result of the expansion of existing capacity or new entries.

Besides better capacity utilization and productivity growth, the World Bank reported the following factors behind the reported growth: 
- Liberalization increased availability of foreign exchange and improved access to strategic raw materials and significantly reduced production bottlenecks. These factors combined with an increased demand impacted positively the average capacity utilization;

- New private investment in manufacturing recorded an average of 2-3 per cent of GDP per annum over the 1992-97 period. The food and wood sectors made more investment than other subsectors. Firms with more than 100 employees invested comparatively more and most of them were new foreign-owned firms (created in the 1990s). Almost, all subsectors made more investment in capital equipment rather than in land and buildings.

Since output and sales were growing at a much faster rate than employment in the period, labour productivity grew almost 30 per cent from 1992 to 1997. Privatization raised manufacturing efficiency as shown by the rapid average growth rates of labour productivity of privatized firms. New investments in equipment and the increasing capacity utilization contributed positively in labour and capital productivity mainly among exporting firms. The resource shift (reallocation of resource) towards efficient firms contributed to increased aggregate manufacturing productivity over time.

However, the average efficiency of manufacturing firms in Mozambique remained below the world average as well as among Southern African Development Community (SADC) members, impairing the country's ability to compete with imported goods and in the world export market. Mozambique's technical efficiency rate remained the lowest across African countries. With the structural adjustment programme, (economic rehabilitation programme, or PRE in Portuguese) and the privatization process the share of manufacturing in the total GDP just declined and slightly recovered, in the period 1992-96 (Figure 8). The manufacturing average share in this period was 8.9 per cent.

Figure 8: The share of manufacturing value added in total GDP (in \%)

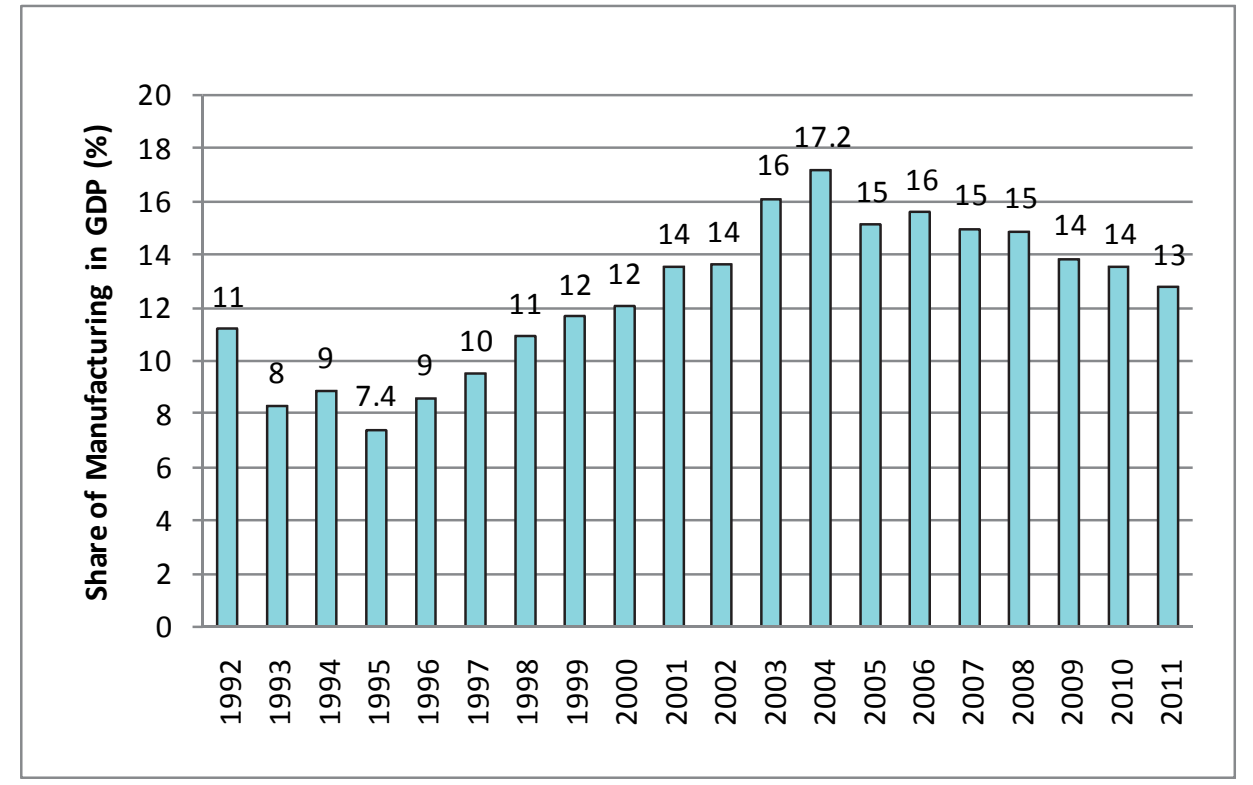

Source: authors, based on INE (2012).

The extreme liberal stance, as well as the Mozambican government's weakness regarding the manufacturing sector development, led to a closure of many bankrupted firms in the second half of 
the 1990s. Even some of the privatized ones failed to survive or grow. One case of privatization failure is the cashew nuts manufacturing companies (Castel-Branco et al. 2001). McMillan et al. (2002) presented a balanced approach, estimating an annual net gain of US $\$ 5.30$ 'for the average cashew-growing household'. However, they recognized that Mozambique suffered a terms of trade loss due to the move from the export of processed nuts to the export of raw nuts.

\subsection{Current industrialization pattern: 1997-2012}

Five years after the 1992 peace agreement with Renamo and three years after the first multiparty and democratic elections, the government approved the 1997 Industrial Policy and Strategy (IPS), (MIC 1997). A description of two main IPS after 1996 and an analysis of the current industrial pattern and economic growth follows.

Industrial policy is made of a set of measures, strategies and activities aimed at increasing economic growth, pushing a country to new frontiers of social development. It is intended to increase output, productivity and the quality of industrial production. Depending on the level of development, industrial policy sets targets for improvements on a wide range of sectors, including, textile, metal works, furniture, agro-industry, fishery, mining and energy, natural resources and technologies. The intermediate objective is to increase the supply of consumption goods and factors of production.

The overall objective of the 1997 policy and strategy paper is to ensure the emergency and development of a modern and competitive industrial base that is less dependent on external resources, including factors of productions. For this purpose, the government calls for: (i) value addition to natural resources; (ii) industry contribution to the balance of payments; (iii) the supply of basic goods; and (iv) the promotion of labour-intensive technologies.

Priority sectors include: (i) the food industry and agro-industry (sugar, cashew, tea, copra, cereals, fruits and cotton); (ii) textile, clothing and footwear industries, (iii) metal and electronic industries; (iv) construction industry; (v) the fishery industry, (vi) mining and (vii) energy.

The 1997 industrial policy and strategy follows a typical liberal approach to industrialization when assigning the roles for the state and the private sector. It reported that the state was going to orient, regulate and supervise the industrial development, while building the appropriate conditions for a robust industrial activity. The channel of interventions included the establishment of industrial policy instruments and the promotion of an appropriate business environment for investors and productions. The paper also expected that whenever necessary the state had the responsibility to set a system of incentives for economic activities, including building complementary investments for attracting the private sector.

The industrial policy and strategy defined the private sector as the appropriate agent for its implementation, being the source of investment, funds, technology and know-how. On the last three issues, a particular role was assigned to foreign direct investment (FDI), due to low levels of savings and expertise among domestic investors.

The government adopted several strategic approaches for implementation of the industrial policy including: (i) setting an enabling environment for private sector development, (ii) the development of micro, small and medium enterprises (MSME), (iii) the creation of training and skill acquisition 
programmes, (iv) the establishment of incentives for investment and (v) the promotion of foreign investment with focus on industrial development and exports.

For attracting foreign investment, particular emphasis was set on the maintenance of political, social and economic stability, the establishment of bilateral agreements to avoid double taxation of investors, and finally, the stimulation of mergers between foreigners and nationals in order to ensure the transference and absorption of know-how

In the area of public investment, the strategy paper focused on the development of infrastructures, including industrial zones and services such as the supply of water and electricity, research and technical assistance and quality control. Additionally, the government indicated the need to participate in priority projects and complementary investments to foster crowding in effects for industrialization.

Regarding access to finance, the government intended to create specific commercial bank credit lines for the industry, thus reducing the bank risk and directing the credit to specific areas and objectives, including MSME, rehabilitation, young entrepreneurs, etc. Additional measures included namely the reduction of the bureaucracy and procedures for access to credit, reduction of the time spent for credit approval and improvement of the financing conditions. Finally, the government targeted the creation of non-bank funds for the industrial development.

Other relevant measures included: (i) the facilitation and simplification of the import procedures for the industrial firms, chiefly regarding raw-materials and intermediate goods; (ii) increasing the amount of exporting industrial firms, by developing commercial information regarding the export markets, fostering quality in the industrial production; (vii) the creation of export processing zones and lastly (viii) the promotion of technological development.

The 2007 Industrial Policy and Strategy defined the general objective of building articulated and multi-sectoral industrialization dynamics (MIC 2007). It is an improvement over the previous IPS, since it defends a more coordinated industrial system and is a more complete and articulated document, including the following components: financing, plan of action, monitoring and evaluation. A drawback is the lack of measurable targets. One debatable shortcoming is the three year time span of the IPS.

This is a broad-based approach, including the agricultural component, import substitution, export promotion, linkage between large projects to small and medium companies, capital- and labourintensive industries and industrial free zones. However, the significant role of the public institutions, driving the industrial policy is implicit.

The 2007 IPS defines eight priority areas in the industrial development: food, furniture, construction materials, recycling, mechanical engineering, metalworking, electrical engineering and chemistry. It also includes the utilization of natural gas, coal, heavy sands and the effective use of industrial property rights.

While much more needs to be done, the implementation of the 1997 and 2007 industrial policy and strategy papers led the country to a new stage of industrial development in Mozambique. The country has managed to establish and run, with a relative degree of success, some of the necessary institutions for sustaining industrialization. These include: (i) the Beluluane export processing zone, 
hosting the Mozal smelter project and its suppliers with investment amounting to more than US $\$ 2.3$ billion; (ii) The Nacala rapid development zone; (iii) the Institute for the Promotion of Micro, Small and Medium Enterprises (IPEME); (iv) the statute for micro, small and medium enterprise; (v) the district development fund; (vi) the Maluana technology park; and (vii) a one-stop electronic window for clearing imports. Global players are investing billions of dollars for exploitation of mineral resources, including coal, gas, iron and gold. The reserves of identified coal and gas put Mozambique among the top potential world producers.

Providing a brief overview on 'current industrial pattern and economic growth', manufacturing was left for the market mechanism to determine its shape, while the state focused its role on promoting investment and providing official permission for private investors to start operating, ensuring joint ventures with local representatives (Castel-Branco et al. 2001). This strategy is shaping the enterprise development of Mozambique. Informal firms are dynamic, as shown by recent evidence (Rand and Tarp 2013). However, medium-size companies are relevant for manufacturing, but these companies, in particular in the formal sector and Mozambican-owned are less dynamic in creating jobs. This economy is particularly lacking dynamism in the international competitiveness, as only 3 per cent of sampling manufacturing companies is exporting.

Evidence from enterprise development is provided by joint surveys carried out by the Ministry of Planning and Development, the Confederation of Trade Associations (CTA) and the University of Copenhagen. Reports on these surveys have revealed an improvement in business environment between 2002, 2006 and 2011, according to businessmen perceptions (Byiers and Rand 2006; Rand and Tarp 2013). The World Bank Doing Business results indicate that Mozambique's relative position to all countries has declined from 130/183 in 2010 to 139/189 in 2014 (World Bank 2011, 2012; 2013; 2014). However, this country is closer to frontier, from 56.4 points in 2006 to 45.02 points in 2014. Other authors have also provided evidence and analysis on enterprise development (ICA 2003; 2009; Warren 2010; Krause and Kaufmann 2011).

Byiers and Rand (2006) showed that micro firms tended to have higher rates of survival (97 per cent) than small (91 per cent), medium ( 93 per cent) and large ( 92 per cent) companies, between 2002 and 2006, on a survey of 118 companies. Medium-size firms bear the main burden of revenueraising efforts (2006). Bribe was more solicited for medium (17 per cent) and large (29 per cent) companies than for micro ( 7 per cent) and small (14 per cent) ones (2006).

Regarding employment growth between 2002 and 2006, micro firms experienced an average increase in 41 per cent, small 35 per cent, medium 26 per cent and large a decline of 53 per cent (Byiers and Rand 2006). For the period between 2006 and 2011, micro firms had an average growth of 2 per cent, small of 6 per cent, medium had a decline of 6 per cent, informal firms experienced an increase of 8 per cent and formal companies had a decline of 2 per cent, Mozambican-owned firms had a decline of 11 per cent and foreign-owned firms an increase of 14 per cent (Rand and Tarp 2013).

In the 1990s, Mozambique followed a significant privatization process as part of the SAP. Campbell White and Bhatia (1998) showed that Mozambique led 10 African countries with 548 privatizations by 1996. By 1999, the government privatized between 1,200 and 1,417 companies (UTRE no date; Castel-Branco et al. 2001).

At the same time, light manufacturing mostly for the domestic market developed from 1995 onwards (Figure 7; Figure 8). A first type of companies was large, for Mozambican economy size, 
like Coca-Cola and SABMiller, with external capital. A second type, although smaller, were operating by exploring activities from thousands of cotton farmers, or through large sugar cane companies. A third category was feeding the construction industry which was booming due to public investments on infrastructures and to private and household investments on housing. A fourth type of firms was informal and a fifth was the medium and large manufacturing companies that managed to keep in business, as discussed by Rand and Tarp (2013). These categories of companies either grew or survived until today.

A sixth successful type of companies were large mining, manufacturing and energy projects, as was the case of Kenmare, a US\$460 million heavy sands extraction and exporting investment in Moma, Nampula province (2004: started construction; 2007: started production); Sasol, a total amount of US $\$ 1.0$ billion natural gas extraction and exporting investment in Pande and Temane, Inhambane province (2002: construction; 2004: production); Vale, a US $\$ 1.26$ billion coal extraction and exporting investment in Moatize, Tete province (2007: construction; 2011: production); Rio Tinto, a US\$849 million coal extraction and exporting investment in Benga, Tete province (2009: construction-Riversdale; 2011: production; 2012: exporting); Mozal, a US $\$ 2.3$ billion aluminium smelter investment in Matola, Maputo province (1998: construction; 2000: production); Cahora Bassa, the main hydroelectric dam in the country, of which the majority of capital was transferred to the Mozambican government in 2007 with the expectation to boost national revenues (1969: construction; 1974: production), (ACIS no date; Andersson 2002; CIP 2013; EBSCO 2007; ImMining 2013; MPD et al. 2011; MPD 2012a; SourceWatch 2013a, 2013b, 2013c; TMSA 2011).

Mega-projects have been under public scrutiny, due to the low contribution to state revenues and the low degree of integration with the rest of the economy (Castel-Branco 2008; Castel-Branco 2010; CIP 2013). On the other side, these projects are considered to have increased the country's visibility among international investors; to have exposed local institutions to large investing companies; to contribute to state revenues in the longer run, in particular after the 2007 law approval; to have reasonable connections with local companies (Andersson 2002; MPD 2012b). The evidence shows that large projects tend to have a one-off effect in the economy, but their individual impact on growth tends to decline in time and their share in the GDP structure also tends to decline (Figure 7; Figure 8). Currently and in the near future, until mid- and end-2020s, the expected growth in coal and natural gas exports should have an accumulated significant impact on GDP growth and volume.

Industry and manufacturing, in particular, have had a mixed role on economic growth and development in Mozambique, as shown by different perceptions (GOM 2005; Jones 2006; ICA 2009; Castel-Branco 2010; Jones and Tarp 2012; Rand and Tarp 2013). These sectors have contributed to accelerate growth between 1995 and 2004 and have diversified somehow the domestic set of products, given that in the 1980s and early 1990s output had declined significantly. This is not a comparison with the 1960s and 1970s.

The role of industry as well as manufacturing on growth and development is complementing the role of most of the other economic sectors. On aggregate, economic growth has been diversified in Mozambique. The production for the domestic market has been dominating compared with the production for exports. External savings and FDI were having a significant role in boosting growth in the 1990s and 2000s, but internal savings have also contributed, through family investments on education, housing and businesses in the late 1990s and the 2000s. 
This last assertion requires additional research in order to provide evidence and demonstration. But, it is a reasonable assumption, given that other explanations for growth until the mid- and end of the 2000s, either considered that the economy did not have a strong basis for sustaining growth after the post-conflict environment, or did not to foresee the resilience of Mozambican economic growth during the international financial and economic crisis in 2008-09, or did not even foresee the upward trend on economic growth after 2009 (Jones 2006; ICA 2009; IMF 2009; Rand and Tarp 2013). The International Monetary Fund (IMF) forecasted a growth rate of 4.3 per cent for 2009 and 4.0 per cent for 2010, when the government of Mozambique forecasted 6.1 per cent for 2009. Actual real annual GDP growth rates for 2009 and 2010 were 6.3 per cent and 7.1 per cent, respectively. Although, some of the authors identify strong internal growth factors like education gains (Jones 2006), they tend to minimize internal factors of growth, focusing on foreign aid and on FDI, in particular on megaprojects. Other factors contributing for growth are investments on institutions, on infrastructure, on human capital, on the broad sense, which includes health, education and social networks and productivity gains (GOM 2005) from both labour and capital.

Access to funds from Asia and other commercial credits are having an additional contribution to growth, from 2010 onwards. This is now, largely recognized, as well as the risk of the country incurring in large and unsustainable external and internal debt.

The weak role of industry and manufacturing on the structural transformation has been argued by Castel-Branco (2003), Jones and Tarp (2012) and Rand and Tarp (2013). The weak growth and diversification of industrial activities and manufacturing products; the lack of inter-industrial linkages, including with agriculture, fisheries and other related sectors; the weak productivity in agriculture are signs of unsustainable growth patterns. These conditions also represent a risk of fuelling social instability due to the still high proportion of poor families and the high level of income inequality, in particular in the cities, and between high income families in the urban areas and families in rural areas.

\section{The structure of the industrial sector}

\subsection{Industrial output}

Mozambique's industrial sector includes four major groups: mining, manufacturing, electricity and water and construction. Utilizing a national accounts GDP series from the National Institute of Statistics (INE, in Portuguese) since 1991, the sectoral structure has stabilized between 2005 and 2011. Manufacturing is the largest sub-sector with 60 per cent of its value added on the total industry value added, followed by electricity and water ( 21 per cent), construction (13 per cent) and mining (6 per cent), (Figure 9). This trend will be significantly changing in favour of mining, from 2012 onwards, with the exports of coal and later on from natural gas.

The rest of this section describes the industrial structure in more detail for 2006-09, based mostly on the set of companies covered by INE's Enterprise Annual Survey (INE 2009-11). These surveys may provide different information than from other surveys mentioned above.

Within the manufacturing sector, the food and beverage industry generated 36.3 per cent of the manufacturing sector production in 2009. Metal works had the largest share (43.1 per cent). Production, transport and distribution of electricity, gas and hot water produced 83.3 per cent of the 
electricity and water output. The largest contributors to the construction sector are engineering (69.7 per cent). Housing and building of public infrastructure had the second largest share (30.3 per cent). The mining industry includes the production of uranium, gold, gas and coal.

Figure 9: The share of mining, manufacturing, electricity and water and construction on total GDP, 1991-2011 (in \%)

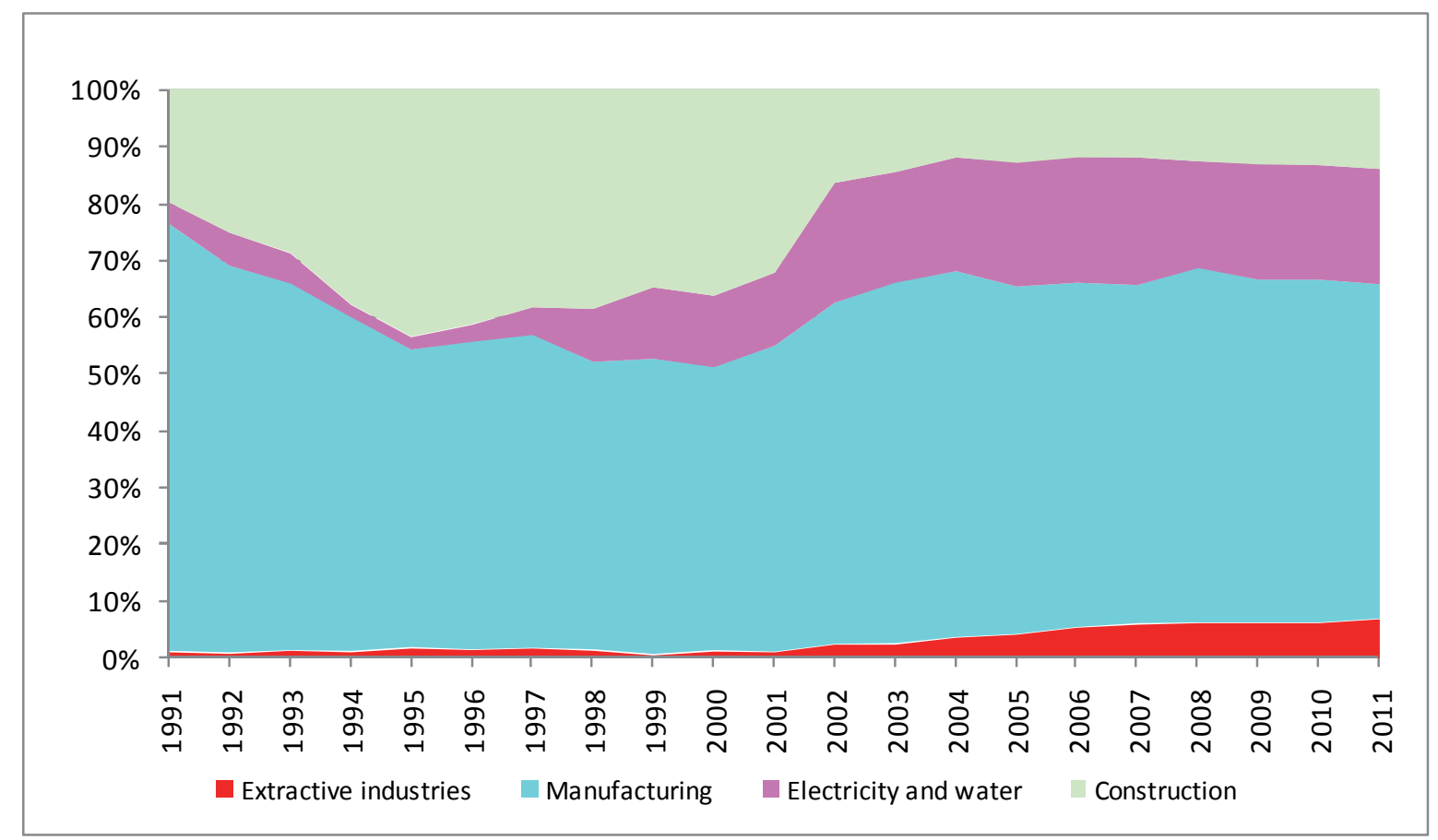

Source: authors, based on INE (2012).

Within the manufacturing sector, food, beverages, tobacco and metal works are among the largest producers, on aggregate. The extractive industry contribution to GDP increased by 1.4 per cent. The share of electricity, water and the construction industry declined between 2007 and 2008, but improved in 2009.

\subsection{Firm size in the industrial sector}

Between 2006 and 2009, the number of firms in the industrial sector increased by 61.5 per cent. This was driven by the growth reported among the manufacturing sector producers (Figure 10). As the figure below reports the number of manufacturing sector firms had an average growth of 87 per cent. The construction sector accounted for 9.8 per cent, 1.36 per cent for mining and 1.03 per cent for electricity and water.

To assess the distribution of firms by size, this paper considers the number of employees, based on INE's data (Table 9). Firms with less than ten workers are considered micro, between 10 and 29 are small, 30 and 99 are medium. Large firms have more than 100 workers. Almost 90 per cent of the Mozambican industrial sector is composed by micro and small enterprises. There are just 6.6 per cent medium enterprises while 4.5 per cent are large firms. Most large firms are found within the mining, electricity and water sectors. They tend to be capital-intensive and they demand high level of investment. 
Figure 10: Number of firms in the industrial subsectors, 2006-09

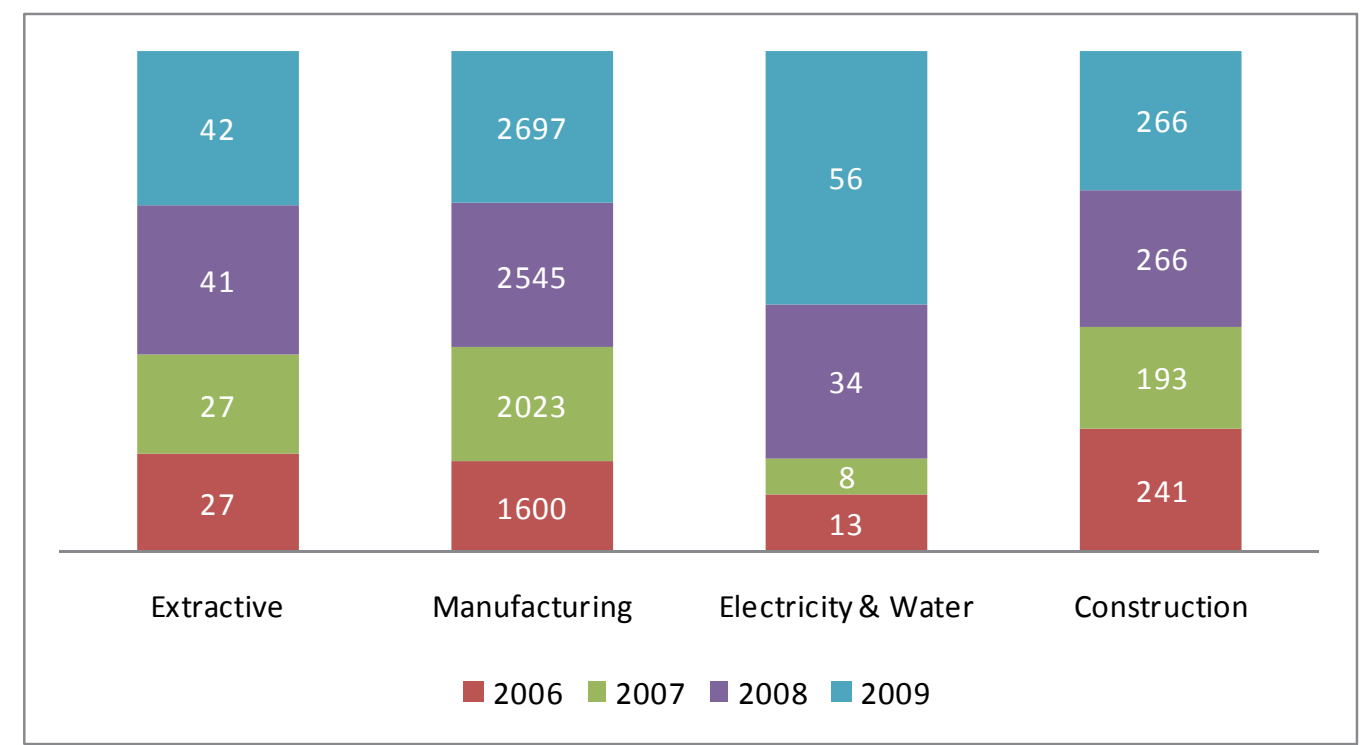

Source: INE (2009-11).

Table 9: Size of firms in industrial sub-sectors, 2009

\begin{tabular}{|c|c|c|c|c|c|c|c|c|c|c|c|}
\hline \multirow{3}{*}{$\begin{array}{l}\text { Size of } \\
\text { company }\end{array}$} & \multirow{3}{*}{$\begin{array}{l}\text { Number of } \\
\text { employees }\end{array}$} & \multicolumn{8}{|c|}{ Industrial sub-sectors } & \multirow{2}{*}{\multicolumn{2}{|c|}{$\begin{array}{l}\text { Total of industral } \\
\text { sector }\end{array}$}} \\
\hline & & \multicolumn{2}{|c|}{ Extractive } & \multicolumn{2}{|c|}{ Manufacturing } & \multicolumn{2}{|c|}{ Electricity \& Water } & \multicolumn{2}{|c|}{ Construction } & & \\
\hline & & Number & $\%$ & Number & $\%$ & Number & $\%$ & Number & $\%$ & Number & $\%$ \\
\hline Micro scale & $(1-9)$ & 9 & 20.9 & 2,155 & 79.9 & 22 & 39.3 & 94 & 35.3 & 2,280 & 74.5 \\
\hline Small scale & $(10-29)$ & 12 & 27.9 & 320 & 11.9 & 18 & 32.1 & 90 & 33.8 & 440 & 14.4 \\
\hline $\begin{array}{l}\text { Medium } \\
\text { scale }\end{array}$ & $(30-99)$ & 13 & 30.2 & 146 & 5.4 & 8 & 14.3 & 36 & 13.5 & 203 & 6.6 \\
\hline Large scale & $>=100$ & 9 & 20.9 & 76 & 2.8 & 8 & 14.3 & 46 & 17.3 & 139 & 4.5 \\
\hline Contribution & f sub-sectors & 43 & 1.4 & 2,697 & 88.1 & 56 & 1.8 & 266 & 8.7 & 3,062 & 100.0 \\
\hline
\end{tabular}

Source: INE (2011).

\subsection{Contribution of the industrial sector on employment}

The industrial sector contribution to total employment averaged 37.0 per cent between 2006 and 2009 (calculated from Table 10). The largest share of new employment came from the manufacturing sector, 69.6 per cent. The mining and the electricity sectors share in new employment was 2.7 per cent and 5 per cent, respectively. 
Table 10: Employment in industry and sub-sectors, 2006-09

\begin{tabular}{|c|c|c|c|c|}
\hline Industry/sub-sectors & 2006 & 2007 & 2008 & 2009 \\
\hline Total employment in industry & 81,388 & 96,004 & 87,498 & 109,507 \\
\hline $\begin{array}{l}\text { Contribution of the sector as a } \\
\text { percentage of total employment }\end{array}$ & 36.7 & 40.8 & 33.1 & 37.3 \\
\hline \multicolumn{5}{|c|}{ Sub-sectors contribution in industrial sector (\%) } \\
\hline Mining & 2.6 & 2.7 & 2.8 & 2.6 \\
\hline Manufacturing & 66.9 & 71.3 & 71.6 & 68.5 \\
\hline Electricity \&water & 6.3 & 4.5 & 3.0 & 6.2 \\
\hline Construction & 24.2 & 21.5 & 22.6 & 22.8 \\
\hline Total & 100.0 & 100.0 & 100.0 & 100.0 \\
\hline
\end{tabular}

Source: INE (2009-11).

\subsection{Ownership of industrial firms}

Table 11 reports the distribution of firms according to the type of ownership. The largest share of industrial firms in Mozambique is composed of private-owned companies. In fact the domestic private sector-owned 75.88 per cent of firms, 3.27 per cent were from the public sector, 20.85 per cent belonged to foreign investors.

Table 11: Distribution of sub-industries and industry by property type, 2008

\begin{tabular}{|c|c|c|c|c|c|c|c|c|c|c|}
\hline \multirow{3}{*}{$\begin{array}{c}\text { Type of } \\
\text { ownership }\end{array}$} & \multicolumn{8}{|c|}{ Industrial sub-sectors } & \multirow{2}{*}{\multicolumn{2}{|c|}{$\begin{array}{l}\text { Total of industral } \\
\text { sector }\end{array}$}} \\
\hline & \multicolumn{2}{|c|}{ Extractive } & \multicolumn{2}{|c|}{ Manufacturing } & \multicolumn{2}{|c|}{ Electricity \& Water } & \multicolumn{2}{|c|}{ Construction } & & \\
\hline & Number & $\%$ & Number & $\%$ & Number & $\%$ & Number & $\%$ & Number & $\%$ \\
\hline Public sector & 135 & 5.5 & 935 & 1.5 & 1,393 & 53.7 & 396 & 2.0 & 2,859 & 3.3 \\
\hline $\begin{array}{l}\text { Domestic } \\
\text { private }\end{array}$ & 1,837 & 75.3 & 48,819 & 77.9 & 859 & 33.1 & 14,879 & 75.2 & 66,394 & 75.9 \\
\hline Foreign private & 466 & 19.1 & 12,938 & 20.6 & 340 & 13.1 & 4,499 & 22.8 & 18,243 & 20.9 \\
\hline Total & 2,438 & 2.8 & 62,692 & 71.7 & 2,592 & 3.0 & 19,774 & 22.6 & 87,496 & 100.0 \\
\hline
\end{tabular}

Source: INE (2010).

The manufacturing sector hosts the majority of firms owned by domestic investors. Due to historical reasons and efficiency considerations, the public sector is dominant within the electricity and water sector.

\subsection{Sunset and sunrise industries}

Between 2006 and 2009, there is evidence of new firms entering the manufacturing and mining sectors. The number of micro manufacturing enterprises increased from 1,184 firms in 2006 to 1,972 in 2009 . From 186, the number of small manufacturing enterprises increased to 355 . The expansion of mining firms happened among micro firms. It went from one micro mining firm in 2006 to 11 in 2009, while the number of small mining increased from five to ten. The number of construction companies is also increasing, as well as the investment in energy production.

The manufacturing sector death rate of firms is high. For Mozambique this is particularly so among small and micro enterprises from the food and beverage sub-sector. As an example, in the second 
half of 2013, three companies closed down or transformed into importing companies in southern Mozambique: cardboard packaging, paints and matches. In this area, Mozambique is finding it hard to compete with manufacturing companies from South Africa.

\section{$4 \quad$ The industrial policy framework}

This section discusses the macroeconomic, water, energy, trade policies as well as the institutional and regulatory framework that shape Mozambique's industrial landscape after the introduction of PRE in 1987 and the peace agreement in 1992. The government embarked on privatization and liberalization programme aimed at enforcing the role of market forces as the main engine for growth. The degree to which the reported reforms were successful on putting the country on the right track towards industrialization remains a contentious issue. While market-friendly reforms were successful in re-opening the space for private sector development, a number of issues remain unsolved from the policy perspective. The policy and institutional framework still maintains a few bureaucratic features of a pro-active public sector, despite moving to a relatively liberal policy approach.

\subsection{Macroeconomic policies}

Mozambique's fiscal and monetary policies follow the standard IMF and World Bank supported programmes. Since 1987, the government objective has been to ensure a sustained reduction on the government primary deficit, money supply control and a declining inflation. The basic assumption behind the adoption of these objectives was that the country's macroeconomic imbalances of the 1980s were due to massive state interventionism, coupled with a lack of control over money supply and declining output. The set of fiscal policy instruments initially used included therefore the privatization of state assets, the removal of price controls and subsidies, tax reforms such as the introduction of value added tax (VAT) in 1999. To ensure inflation control, the Bank of Mozambique introduced direct monetary controls, besides privatization of the banking sector and liberalization of interest and exchange rates.

As reported above, by the end of 1999 Mozambique had privatized more than 1,200 state companies (Andersson and Sjö 2002). At the beginning of the 2000s, Mozambique was regarded as one of the most appropriate economies for doing business. Real GDP growth rate averaged 8 per cent between 1992 and 2000. From 2001 to 2003, it remained around 12 per cent, setting the country among the fastest growing economies in the world. Inflation dropped from a level as high as 62.2 per cent between 1987 and 1996 to 14 per cent in 2003. The exchange rate depreciation followed a similar trend, reaching a minimum of 3.3 per cent in 2003.

Table 12 below summarizes growth rates for major sectors and the international trade between 1992 and 1999, with a focus on industry. It emerges that besides robust overall growth records, there are sector-specific differences that are worth mentioning. While agriculture and related activities resumed high growth rates, the fisheries sector failed to follow the pace of the rest of the economy. After three years (1992-94) of decline the manufacturing sector resumed growth in 1995, setting record growth rates. From 7.8 per cent in 1995, the manufacturing sector grew by 18.9 per cent and 31.85 per cent in 1996 and 1997, respectively. 
Table 12: Selected macroeconomic indicators growth rates, 1992-99 (in \%)

\begin{tabular}{lrrrrrrrr}
\hline Description & 1992 & 1993 & 1994 & 1995 & 1996 & 1997 & 1998 & 1999 \\
\hline $\begin{array}{l}\text { Agriculture, animal production, } \\
\text { hunt and forestry }\end{array}$ & -20.6 & 25.5 & -0.4 & 17.0 & 8.7 & 9.5 & 9.5 & 6.5 \\
Fisheries, aquaculture and & & & & & & & & \\
related activities & -10.0 & 7.3 & -6.5 & 2.8 & 10.1 & 2.1 & -11.0 & -2.1 \\
Extractive industry & -27.5 & 24.8 & 2.2 & 20.1 & -19.9 & 21.1 & 20.6 & -6.5 \\
Manufacturing & -7.9 & -5.7 & -6.0 & 7.8 & 18.9 & 31.8 & 14.4 & 14.7 \\
Electricity and water & -0.7 & 3.5 & -3.0 & 6.6 & 18.0 & 37.9 & 279.0 & 78.3 \\
Export & 13.8 & 3.8 & 32.7 & 6.0 & 38.0 & 8.6 & 9.7 & -0.7 \\
Import & -7.8 & 0.8 & 24.2 & -1.9 & -8.0 & 0.4 & 7.6 & 41.5 \\
GDP & -5.2 & 8.8 & 6.2 & 2.2 & 14.8 & 11.1 & 11.8 & 8.4 \\
\hline
\end{tabular}

Source: INE (1993-2000).

The reported growth rates implied changes in the composition of Mozambique's GDP, signalling the emergency of some form of positive structural changes. The share of agriculture reduced from 30.5 per cent in 1995 to 27.4 per cent in 1999 , while the manufacturing share increased from 7.6 per cent to 10.1 during the same period (INE 1993-2000, Table 13).

Table 13: Structure of production, 1992-99 (in \%)

\begin{tabular}{lrrrrrrrr}
\hline Description & 1992 & \multicolumn{1}{c}{1993} & 1994 & 1995 & 1996 & 1997 & 1998 & 1999 \\
\hline Extractive industry & 0.3 & 0.4 & 0.4 & 0.4 & 0.3 & 0.3 & 0.3 & 0.3 \\
Manufacturing & 9.3 & 8.1 & 7.2 & 7.6 & 7.8 & 9.3 & 9.5 & 10.1 \\
Electricity and water & 0.8 & 0.7 & 0.7 & 0.7 & 0.7 & 0.9 & 3.0 & 5.0 \\
GDP & 100.0 & $100.0 \%$ & 100.0 & 100.0 & 100.0 & 100.0 & 100.0 & 100.0 \\
\hline
\end{tabular}

Note: This structure considers shares for implicit financial sector margins and value of taxes on products additional to shares from sectoral valued added, which is different from the method used in Figure 1.

Source: INE (1993-2000).

In 2000s, Mozambique succeeded in maintaining the trend of high economic growth rates. The agricultural sector growth reduced but remained relatively robust. The mining industry became relevant. From a negative growth rate of -6.5 per cent, it grew by 16 per cent in 2003 and 71.6 per cent in 2004. Besides agriculture, it remained the fastest growing sector between 2006 and 2007 (Table 14). 
Table 14: Selected macroeconomic indicators growth rates, 2003-10 (in \%)

\begin{tabular}{lrrrrrrrr}
\hline Description & 2003 & 2004 & 2005 & 2006 & 2007 & 2008 & 2009 & 2010 \\
\hline $\begin{array}{l}\text { Agriculture, animal production, } \\
\text { hunt and forestry }\end{array}$ & 5.2 & 5.1 & 6.9 & 10.4 & 8.2 & 9.3 & 7.1 & 4.9 \\
$\begin{array}{l}\text { Fisheries, aquaculture and related } \\
\text { activities }\end{array}$ & 8.6 & 0.2 & 0.9 & 7.7 & 9.0 & 6.7 & -9.9 & 5.6 \\
Extractive industry & 16.1 & 71.6 & 0.7 & 27.8 & 19.3 & 7.2 & 3.0 & 5.1 \\
Manufacturing & 17.0 & 13.2 & 2.1 & 3.0 & 3.1 & 4.9 & 2.4 & 2.8 \\
Electricity and water & 10.1 & 16.3 & 17.2 & 13.1 & 8.6 & -12.2 & 13.0 & 5.6 \\
Export & 19.0 & 21.3 & 6.3 & 12.2 & 15.9 & 0.3 & 2.3 & 1.8 \\
Import & 4.6 & 1.7 & 5.5 & 1.2 & 12.8 & 18.0 & 1.0 & 0.4 \\
GDP & 6.5 & 7.9 & 8.4 & 8.7 & 7.3 & 6.8 & 6.3 & 6.8 \\
\hline
\end{tabular}

Source: INE (2004-11).

The mining industry now accounts for 1.1 per cent of total GDP (1.4 per cent in Figure 1). After a period of remarkable growth of the manufacturing sector, the growth rate slowed down after 2004. Between 2005 and 2010, the manufacturing sector grew at a lower annual rate than the total GDP. As a result, the sector share on GDP decreased from 14.8 per cent in 2005 to 12.3 per cent in 2010 (Table 15).

Table 15: Production structure, 2003-10 (in \%)

\begin{tabular}{lrrrrrrrr}
\hline Description & 2003 & 2004 & 2005 & 2006 & 2007 & 2008 & 2009 & 2010 \\
\hline $\begin{array}{l}\text { Agriculture, animal production, } \\
\text { hunt and forestry }\end{array}$ & 23.4 & 22.8 & 22.5 & 22.9 & 23.1 & 23.6 & 23.8 & 23.3 \\
$\begin{array}{l}\text { Fisheries, aquaculture and related } \\
\text { activities }\end{array}$ & 1.9 & 1.8 & 1.7 & 1.6 & 1.7 & 1.7 & 1.4 & 1.4 \\
Extractive industry & 0.6 & 0.9 & 0.9 & 1.0 & 1.1 & 1.1 & 1.1 & 1.1 \\
Manufacturing & 15.0 & 15.7 & 14.8 & 14.0 & 13.5 & 13.2 & 12.7 & 12.3 \\
Electricity and water & 4.6 & 4.9 & 5.3 & 5.5 & 5.6 & 4.6 & 4.9 & 4.8 \\
GDP & 100.0 & 100.0 & 100.0 & 100.0 & 100.0 & 100.0 & 100.0 & 100.0 \\
\hline
\end{tabular}

Source: INE (2004-2011).

The current monetary and fiscal policy framework is relatively consolidated by SSA standards. Following successful financial sector reforms and development, the Bank of Mozambique now relies on indirect monetary controls for inflation management. Inflation and the exchange rate remain under control and in line with the government target. In 2012, the average inflation and exchange rate depreciation were 7 per cent and 3 per cent, respectively.

Following fiscal reforms such as the introduction of a new personal income and corporate taxes in 2003, the government set up the Mozambique Revenue Authority in 2006, merging in the same entity, the tax collection activities of different units within the Ministry of Finance.

This was followed by reforms of the tax administration and the investment tax code. To attract private investment, Mozambique provides generous tax incentives for investors, including the right for profit repatriation. The country's fiscal stance improved as a result. The share of total tax on GDP, increased from close to 11 per cent in 2000 to 24 per cent in 2012. 
Despite this improvement, the tax system is still considered inefficient for industrial development. There are close to 42 taxes to be paid in Mozambique against an average of 12 in neighbouring countries (SPEED 2013). This includes: (i) a value added tax at 17 per cent, (ii) corporate income tax at 32 per cent; (iii) personal income tax at increasing rates up to 32 per cent; (iv) stamp duty, varying from 0.02 per cent to 4 per cent; (v) excise tax, increasing to rates above 50 per cent; (vi) fuel tax; (vii) contributions to social security at 7 per cent; (viii) license fees.

Investors that use the investment promotion centre have access to fiscal, exchange control and import duty benefits. For access, the investor should be willing to invest more than US\$50,000.00, if foreign and US $\$ 5,000.00$ for a local business. One of the obligations for access to fiscal benefits is that the companies should hold audited accounts. This provision prevents easy access for small businesses, constituting an additional burden for doing business.

Additionally, various discussions on the tax system report that it is not conducive for manufacturers because of the following problems: (i) uneven application of the tax regime; (ii) lack of guidelines to fully comply with tax requirements; (iii) complicated and time-consuming procedures; (iv) delays in VAT refunds; and (v) breaks in the VAT chain (FIAS 2006). The marginal effective tax rate for manufacturing ranges from 11 per cent to 40 per cent. The number of taxes that firms have to pay annually is not indeed the biggest problem for companies in Mozambique, but the high rates and the required procedures for tax payment (SPEED 2013).

\subsection{Trade policies}

For a developing country like Mozambique international trade represents the best alternative approach against poor savings, lack of physical and human capital and small dimension of the domestic market. Since the adoption of PRE in 1987, the government of Mozambique has therefore taken measures to free international trade from unnecessary barriers. Export taxes have been removed and import duties for most goods are expected to drop to zero by the year 2015, when the SADC common market becomes operational. Currently the top tariff is 25 per cent, the average applied tariff rate is 12.1 per cent and the trade weighted average tariff is only 9 per cent. Mozambique used ad valorem duties. Despite offering some form of protection in selected sectors, such as the sugar industry, the effective rate of protection in most sectors is lower than most of the SADC members.

For attracting investment, the government established the Investment Promotion Centre in 1994. Through the investment code of 1998 and the subsequent amendment in 2004, the government created free export processing and rapid development zones, where investors enjoy generous tax incentives, including tax exemptions and profit repatriation.

Since the introduction of the first generation of reforms in 1987, trade and capital flows have been increasing as a result of the reported wave of reforms. Exports, mainly directed to South Africa, OECD countries and the USA, have been increasing. This was followed by a marked increase in total capital formation and FDI. Driven by the globalization strategies of South Africa, Portugal, England and China, foreign investment is by far the largest in total capital formation. It flows for development of big projects, including: the banking industry, electricity and the mining industry. Mozambique is considered currently more integrated in the world trade than it was 15 years ago. 
In world ranking, however, the country is still lagging behind due to limitations associated to the way it manages its exports and imports. Out of 181 countries surveyed, Mozambique was ranked at 140, in aggregate evaluation of the process and costs for clearing imports and exports in 2008 (Econex 2009).

FIAS (2008) reported that part of the reason for the poor ranking on all indicators measured above is associated with inefficiencies within the customs administration, including: (i) corruption; (ii) poor physical infrastructure and capacity at the border crossings; (iii) lack of information technology and human capacity among customs; (iv) a high rate of inspection of both export and import shipment, (v) reliance on pre-shipment inspection of imports; and (vi) limitations of the duty drawback/duty suspension and VAT rebate system.

The situation has not changed in the last two years. A typical importer has to follow three stages to import raw materials: (i) hire an import broker to start the import process; (ii) pay the import duties and (iii) clear the imported material and make the appropriate delivery to the factory. The first stage is placed under the supervision of INTERTEK, a pre-inspection company. In the second stage, the importer deals with customs authorities. For receiving the imported materials, after arrival and payment of import duties, the import broker deals with the cargo terminal officers. During the three stages, importers face delays and have to incur additional costs and time loss, compromising an already limited capacity to import, while competing with regional and global giants.

AIMO (2010) estimates that, on average, a typical industrial importer has to spend 55,473.00 MZN for each import made through Maputo cargo terminal, in addition to the required expenditures. This adds to the average cost of inputs, reducing profit margins as well as the competitiveness and performance of the local industry (ANEMM 2000; Marrengula et al. 2012).

\subsection{The institutional and regulatory framework}

By institutions it is meant the set of rules both written and unwritten which regulate the relationship between market players and transactions of goods and services. The market for industrial goods is far from perfect. Both buyers and sellers enter into transaction, requiring a significant amount of capital, under uncertainties and exposed to the two basic problems of asymmetric information: the hidden action and hidden information problems.

The hidden information problem results from the fact that embarking in industrial projects requires a significant amount of information about the market players, quality, reliability and availability of inputs, the level of effort required both in sourcing inputs, producing and selling, costs, technical specifications and their alternatives. The information on these items is frequently not readily available and costly to get. Once the contract for a typically profitable industrial project is awarded, the hidden action problem emerges. Due to the amounts involved the market practices include requests for advances before the project activities are undertaken. Without appropriate enforcement mechanisms, this raises the risks of inappropriate conduct from the producer including minimizing effort, delays, as well as the delivering of poor quality goods.

Theoretically the response for both problems is writing complete contracts but this is impossible. Industrial players are unable to predict every risk since their output is also a function of the business environment. Risks increases with the time-scale involved in delivering the industrial projects. The 
ultimate effects of the reported problems are increased uncertainty and risks when one embarks in industrial projects.

To safeguard their interest against this background, industrial players attempt to use optimal contracts, defining incentives for efforts and adopting insurance and limited liability mechanisms. Suppliers invest in building reputation as a signalling device of capabilities to deliver, while governments introduce standards and regulations for minimizing transaction costs and resolution of business disputes. The basic objective is to raise the level of trust within the market. Successful countries have been effective in enforcing trust and the regulatory framework for doing business in a context of markets with imperfect information.

For the construction industry, for example, this has led to two beneficial and mutually reinforcing events. First, the possibility of enforcing contracts, associated with a more sophisticated judiciary system and regulatory framework set the pace for a more conducive environment for doing business. Second, a better institutional and legal framework is good for lowering the price of financial services, hence increasing the availability of project finance. In fact the availability of project finance at affordable interest rates is fundamental for a sustained take off of construction projects, an important base for sustained industrialization.

Mozambique has introduced reforms on the business environment and the commercial law in order to improve the protection of property rights and increase the level of trust within the business community, including opening the space for arbitration centres, public risk bureau sand the modern regulation regarding industrial licensing and company insolvency.

For investors, Mozambique also offers a number of guarantees, including: (i) guarantees over security and legal protection of property rights; (ii) rights to import of own-equity capital or loans to carry out investment; (iii) entitlement to just and equitable compensation in the event of expropriation based on absolute necessity and weight reasons of public interest, health and public order. Investors also enjoy rights to the remittances abroad, within 90 days, of:

- Payment of royalties and other fees for contracting and transferring technology;

- Loan repayments and interest charges due abroad;

- Amounts paid as just and suitable compensation, if such occurs;

- Repatriation of capital invested upon liquidation or total or partial sale of the undertaking.

The country is a member of the Multilateral Investment Guarantee Agency, the Overseas Private Investment Corporation and the International Convention and Centre for settlement of investment disputes.

While this represents important improvement for a strong industrial base when compared to the past, there are still concerns regarding how the country is building an economy with appropriate checks and balances and business transparence. In related indicators, Mozambique is lagging behind other SADC countries (World Bank 2014).

Out of 134 countries surveyed in the Global Competitiveness indicators, Mozambique ranks 130. It ranks 139 out of 189 in the 2014 World Bank Doing Business index. In the corruption index it ranks 88 out of 145 , while in terms of property rights protection it ranks 116. 
Mozambique's poor performance on the indicators reported above is not a new topic of debate. In fact, they are the target of several public policy instruments. The business environment strategy of 1998 raised them and defined targets to be achieved by 2012. Under the pillar of good governance, the three Poverty Reduction Strategy papers also reported approximate constraints, calling for actions for an effective fight against poverty. Why is Mozambique failing to see a breakthrough in the institutional and regulatory framework?

A frequent answer is that the state lacks financial, material and human resources for rapid changes. But this is only part of the answer. There are cultural and issues of political economy behind the problem. Cultural issues results from the country's historical background. Colonialism provided indigenous Mozambicans with minimum education with a view to use them as cheap labour locally or in a neighbouring country. The most visible educated Mozambican barely had education standard four and their typical employment was with government authorities as clerk, book keeper, etc. This social group made the indigenous elite, while doing business for the local was prohibited and selfemployment was considered the second best alternative and a way to escape from severe poverty. The socialist experiment reinforced this perception. While it removed the ban on indigenous education, it discouraged private property, stimulated the spirit of common wealth, imposing the supremacy of public choices over individuals and insisted on educating people to work for the public sector. Private sector and self-employment were not desirable options for the most talented society members.

The introduction of a market-based economy in the late 1980s and 1990s brought the incentives for a more entrepreneurial society, but it did not change the system of rewards and punishment built in under colonialism and during the socialist experiment. To progress within the social structure the public sector remained the most desirable channel. The state maintained its omnipresence. Where it failed to reach, the donor community filled the gap. While the reasons for both state and donor prominent role are fairly understandable, their interventions hampered the development of a sense of individual responsibility over one's choices and fortune. The market-based economy is growing, besides a slow change of social values. While individuals have freedom to choose the course of their actions, it is expected that both the rewards and punishments resulting from these choices will be socialized.

Moreover, by imposing a burden on individual decision-making, this hampers the development of strong civil society organizations. The socialization of rewards and punishment resulting from individual choices has in fact imposed the supremacy of the state and state officials over individuals, sustaining and justifying, on its own, a centralized form of governance, without the necessary checks and balances. The institution of multiparty democracy has failed to change this.

Behind this background, it is not surprising therefore, that the business community is weak at the local level and away from the decision-making centres. This implies low levels of pressure and information for government officials about local needs and reduces the chances for fruitful intervention. In the absence of strong bottom-up pressure and information flows, it is difficult to generate relevant and major changes in favour of a better business environment.

Changing the outcomes also requires changes in strategy design and the definition of priorities in Mozambique. To date, government strategic plans are broad in approach and limited to specific sectors. Each ministry analyses its own issues, without paying attention to the issues in closely related sectors. This results in wasted resources, because it constrains the establishment of inter- 
related priorities for ministries. It is not surprising that when looking at the ministerial sector strategy, all types of sector objectives and mandates are considered priorities; however, they may not be priorities at the national level. This does not mean that at the cabinet level there is no reconciliation of targets, but there is a difference between cabinet reconciliation and effective implementation at the ministerial and local level.

Solving this problem requires breaking compartments and redesigning government institutions, following a value chain organizational structure. For specific industrial development, a number of bodies, such as the sugar and cotton institutes, have been created in line with this view, but their roles remain limited and it is not clear whether the government considers this approach a valuable asset for industrial development (Marrengula et al. 2012).

There is also evidence of efforts to invest in developing the national standard and quality control framework as well as the country skill and entrepreneurship profile. The number of vocational schools increased from 36 in 2009 to 44 in 2012 (Table 16).

Table 16: Number of vocational and technical schools

\begin{tabular}{lrrrrr}
\hline Level & 2009 & 2010 & 2011 & 2012 & Growth rate \\
\hline Vocational schools & 36 & 36 & 41 & 44 & $22 \%$ \\
Technical schools & 27 & 28 & 30 & 28 & $4 \%$ \\
Total & 93 & 93 & 100 & 102 & $10 \%$ \\
\hline
\end{tabular}

Source: GOM (2012).

From 5,810 in 2009 , the vocational schools student population increased to 7,871 in 2012 , an estimated growth rate of 35 per cent (Table 17). The growth rate of students enrolled in technical school was 6 per cent during the same period.

Table 17: Vocational and technical education enrolment

\begin{tabular}{lrrrrr}
\hline Level & \multicolumn{1}{c}{2009} & \multicolumn{1}{c}{2010} & \multicolumn{1}{c}{2011} & \multicolumn{1}{c}{2012} & Growth rate \\
\hline Vocational schools & 5,810 & 6,318 & 7,662 & 7,871 & $35 \%$ \\
Technical schools & 12,699 & 12,570 & 13,913 & 13,498 & $6 \%$ \\
\hline Source: GOM (2012). & & & & &
\end{tabular}

Though there are increased concerns over the quality of the education supplied, enrolment rates increased among higher education institutions. The average growth rate in enrolment among public institutions was close to 19 per cent between 2009 and 2012 (Table 18). The total enrolment was 25 per cent, boosted by the expansion of the private universities enrolment (41.5 per cent).

Besides advocating for reforms of the education system, towards the beginning of the implementation period of the industrial policy, the government and the donor community adopted a more pro-active approach towards the development of the local private sector and entrepreneurship. Following this shift, three institutions were set up, namely: UNDP's Enterprise Mozambique; the United Nations Industrial Organization (UNIDO) and Mozambique Industrial Association (AIMO)'s Industrial Development Advisory Centre and the World Bank's Private Sector Development Program. The first two run entrepreneurship training programmes for trainers, aspiring entrepreneurs, businessmen and mid-level managers. The World Bank's private sector 
development programme provided financial support for companies willing to upgrade the entrepreneurial and managerial competencies of their staff, besides financing other aspects deemed crucial for enterprise development. Besides these initiatives, the government in partnership with donors opened financial institutions targeting small and medium enterprises (SME). The reported financial institution service portfolio included financing, training and business counselling.

Table 18: Higher education enrolment

\begin{tabular}{llrrr}
\hline & 2009 & \multicolumn{1}{c}{2010} & \multicolumn{1}{c}{2011} & Growth rate \\
\hline Public & 60,949 & 75,705 & 72,636 & $19,2 \%$ \\
Private & 20,301 & 29,778 & 28,726 & $41,5 \%$ \\
Total & 81,250 & 105,483 & 101,362 & $24,8 \%$ \\
\hline
\end{tabular}

Source: GOM (2012).

More recently, due to the high rate of unemployment, IPEME introduced the SME promotion strategy, paying particular attention to the promotion of an entrepreneurship promotion programme, access to finance, business services, removal of regulatory constraints and tax burdens. IPEME is currently working to set up her first network of incubators.

The Ministry of Education initiated two major entrepreneurship education programmes, including curriculum reforms aimed at developing life and entrepreneurship skills among teachers as well as primary and secondary schools graduates.

At secondary school level, the Ministry of Education's entrepreneurship promotion strategy involved teaching entrepreneurship from standard 8 to 12, besides developing student's competencies in agriculture, livestock, and information and communication technology. The introduction of entrepreneurship has a financial and technical support from UNIDO. The programme's objective is to develop entrepreneurial attitude and culture among secondary school graduates while providing the required knowledge to start and run a small scale business. Since its inception in 2007, in a pilot phase, the programme has covered around 240,000 students throughout the country, 255 schools, 1,521 teachers and 52,309 secondary school graduates.

This is by far the biggest entrepreneurship education programme in Mozambique, but its sustainability greatly depends on how the government will handle the next phase of expansion to all secondary schools after UNIDO's support has come to an end in 2013.

There is no a documented evaluation of how successful the Mozambican overall policy framework and the industrial policy, in particular, has been. Recent studies carried out by the Mozambique Industrial Association (AIMO), CTA and the World Bank, while recognizing progress, they report some of the general weaknesses raised in the area of taxes, international trade and institutions, besides limitations of infrastructure, the costs to get access to utilities, the continuing scarcity of manpower, finance, technology and credibility constraints (AIMO 2010; World Bank 2013).

\subsection{Access to energy}

Mozambique's energy market is monopolistic in both production and distribution. Until PRE's implementation in 1987, the fuel market was dominated by PETROMOC, a state-owned company. The liberalization that followed the adoption of PRE allowed entry for new brands, but 
PETROMOC is still a dominant player. There is a similar situation in the electricity market. Electricidade de Moçambique (EDM) is a state-owned company, supplying more than 90 per cent of the electricity distributed in Mozambique. This is a side effect of the socialist experiment, but it has also economic rationale since both sectors tend to result in natural monopolies or become highly concentrated, when left for free competition.

Recent reforms of energy law allow for concessions, public-private partnership and the entry of private sector players both for production and distribution. It is not clear to what extend the reforms introduced managed to create a transparent and fair environment for both private and public sector players. They are, however, signs of positive development.

For the period of 2000-10 the government made a commitment to expand electricity in order to cover more districts, with a view to foster the emergence of new enterprises and boost economic development locally. The EDM's statistical summary (2010) shows a sustained increase in coverage, from 59 rural villages covered in 2005 to 97 in 2010 (Figure 11).

Figure 11: Capital districts electrified (in colour)

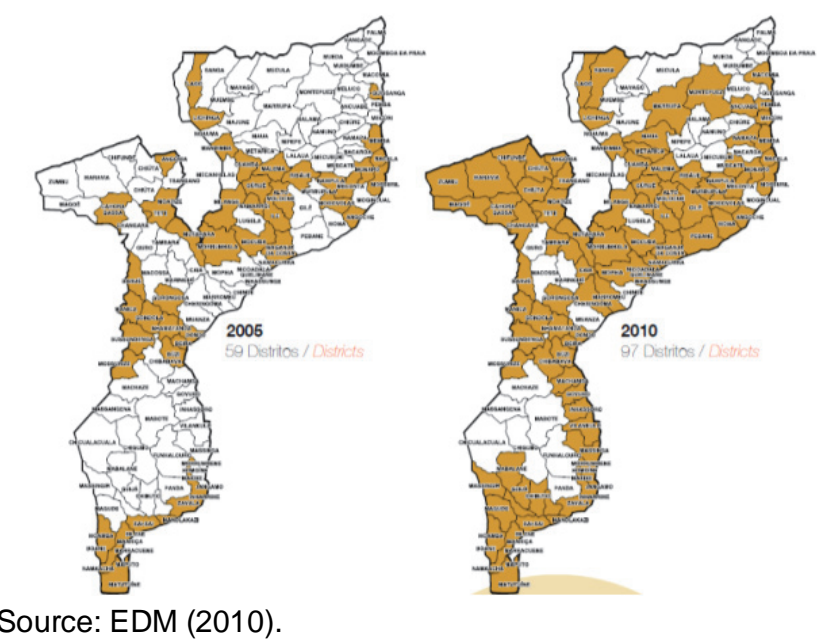

Electricity services increased their national consumer coverage from 5 per cent of the total in 2001 to 16 per cent in 2010 (EDM 2010). Southern Mozambique has been benefitting from access to energy more than others regions by increasing the consumer coverage from 12 per cent in 2001 to 37 per cent in 2010 .

The long-term implication of this trend and the reported reforms to the industrial sector will depend on additional government policies and how the electricity market itself will evolve. So far the available conditions remain unfavourable for the industry when put in a comparative setting (Econex 2009).

The average value of electricity/MW $\mathrm{h}$ is above the average of South Africa and Lesotho. It is on a comparable level with Zambia. Econex (2009) also reports, using data of 2006, that EDM charges the highest prices for electricity, when compared to their counterpart in Malawi, Tanzania, Swaziland, Zambia and South Africa. For small business and services, EDM charges US $\$ 55$ for 450 $\mathrm{kW}$ h against US $\$ 40$ from Eskom in South Africa. Malawi and Tanzania charge US\$24 and US\$38, respectively. 
The problem with energy is not just of costs. Close to 70 per cent of the members of the Federation of Industry (AIMO-FI) interviewed in 2011, considered the access to reliable and regular supply of electricity a fundamental constraint for their productivity. The country has low electricity density, despite the existing potential. It is sixth in the region in terms of density of electricity network. The negative impact of this is deepened by the uneven distribution of the network and the limited focus on areas and sectors with high economic potential. The problem of reliability of electricity supply also translates into frequent power cuts (on average five to 10 times per week), taking at times more than 30 minutes. This situation worsens when one moves from the Maputo metropolitan area to the north.

There are three reasons for the poor performance of the energy sector in Mozambique. First, the available production and distribution capacity is limited. Due to historical reasons, while production of most of the electricity is ensured by the Cahora Bassa Dam in Mozambique, the transformation for consumption has to be undertaken in South Africa, by Eskom, the South African power company. This adds to the costs not only because of the associated transport costs but also because Eskom enjoys monopoly power as a buyer and a seller. Second, due to social consideration and urbanization, Mozambique has been investing in expanding the distribution network, but it is devoting a relatively reduced amount of resources for maintenance and production capacity, leading to overloaded electricity production infrastructure. Third, EDM in the electricity sector and PETROMOC in the market for fuel enjoy significant market power. In a small and poverty-stricken economy such as Mozambique, this leads to the temptation to overcharge those customers whose demand for energy resources is inelastic, companies. This occurs where competition laws do not exist or are ineffective.

\subsection{Access to water}

As in the energy sector the situation is not different in the water market (Econex 2009). Mozambique's tariff for renting of a counter is almost four times the equivalent South African's tariff. The payment of water up to 50 cubic meters for industrial use is US $\$ 35 /$ month, almost the value charged for mines in South Africa.

Mozambique is blessed with plenty of fresh water. As Econex (2009) argue, its use is, however, inefficient, constraining the productivity of water-intensive industries. Following the water reform process initiated with the creation of the national fund for water during the second half of the 1990s, water production and coverage increased. However, the system is still considered inefficient and exposed to frequent interruptions. As a result, companies have to hire private water supply agents and invest in water distribution and conservation equipment.

\subsection{Business environment}

Mozambique ranked 139 on doing business 2014, out of 189 countries, from ranking 142 out of 185 in 2013 and 139 out of 183 in 2012 (Figure 12). According to the World Bank (2012) the following factors sustain Mozambique's current position: (i) lack of infrastructure; (ii) limitation on access to credit; (iii) bureaucratic constraints associated to access to land, starting business, getting the related licenses and import barriers. The following sub-sections discuss the most binding constraints based on the World Bank Doing Business reports and other available literature. 
Figure 12: Mozambique ranking on World Bank Doing Business, 2012

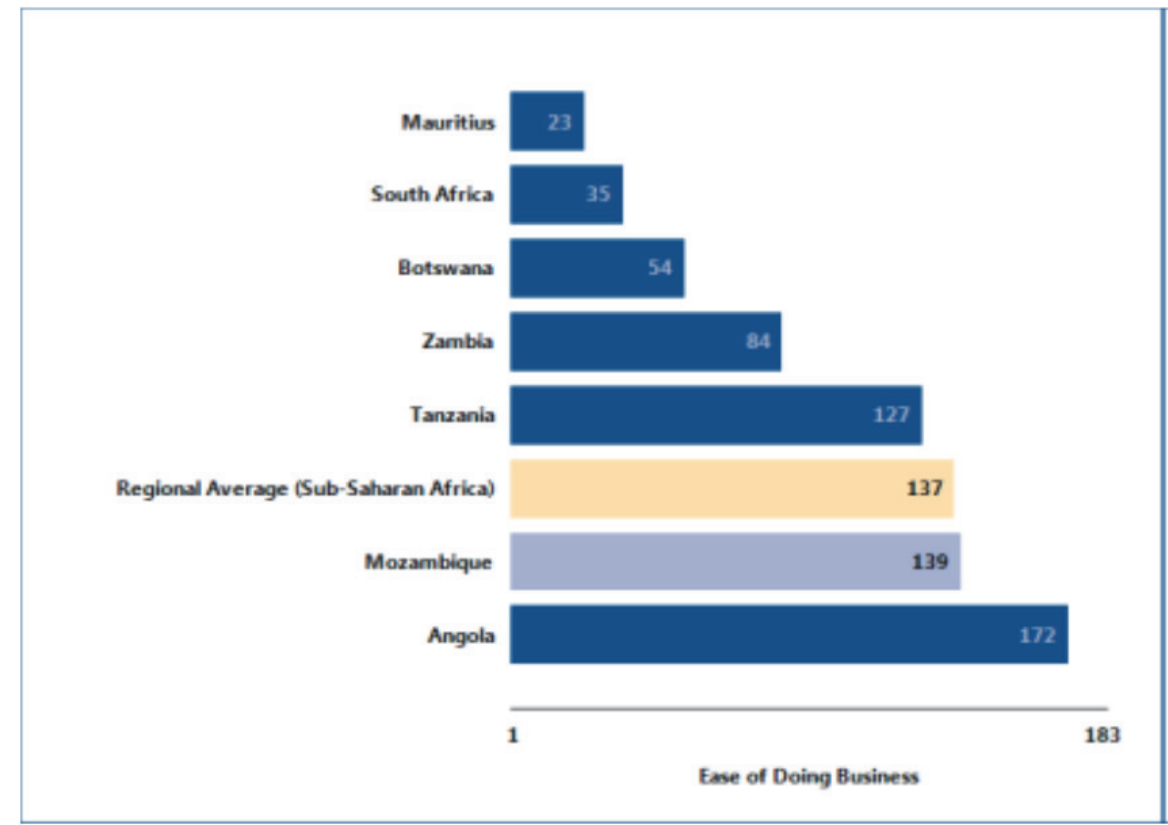

Source: World Bank (2012).

On specific institutional issues, the World Bank Doing Business report for 2013 is summarized in Figure 13.

Figure 13: Mozambique's ranking by business topics, 2013

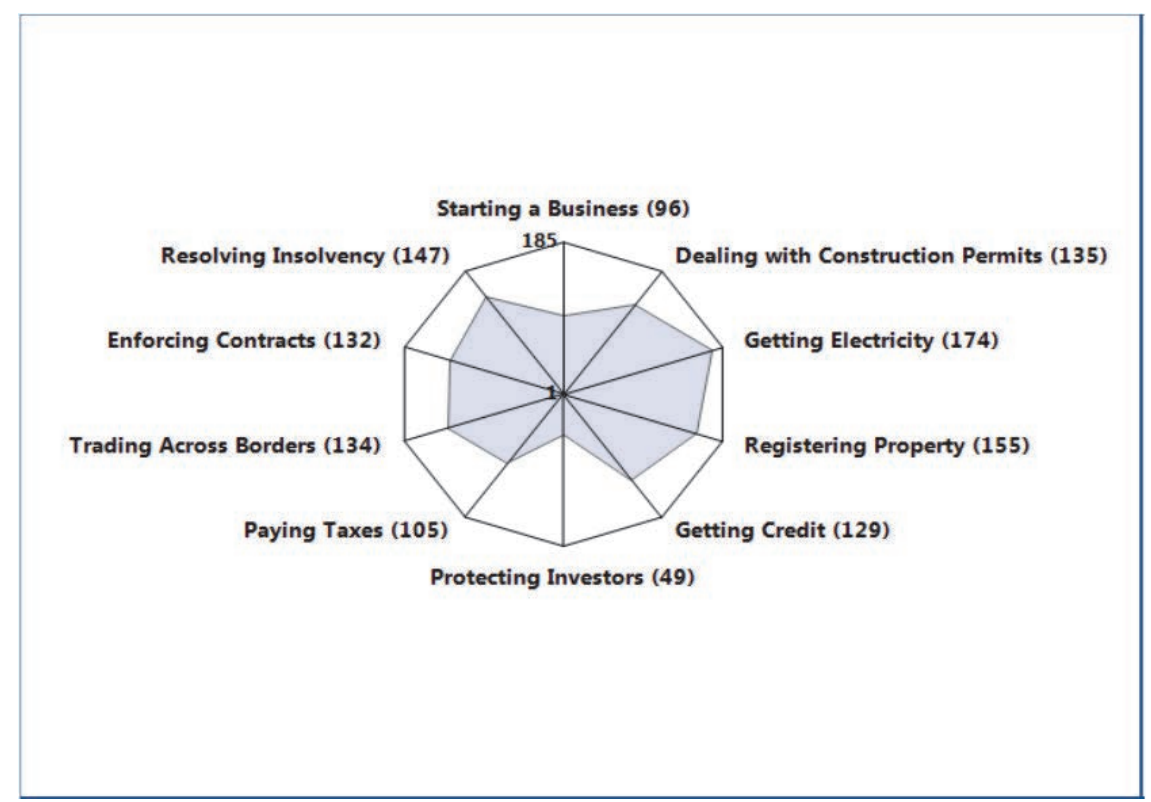

Source: World Bank (2013). 


\subsection{Skills}

Mozambique's labour force qualifications are limited. Fifty-two per cent of Mozambique's population is illiterate. According to the National Institute of Professional Training and Employment, 80 per cent of illiterate Mozambicans have no professional qualifications (MITRAB 2006). Ninety per cent of those applying for their first job have not finished basic education. Among them the majority (62 per cent) have no work experience or qualifications.

The situation is not different among those sectors with high growth potential such as the construction industry, tourism and agriculture (ANEMM 2000; AIMO 2010). For example, within the building materials industry, more than 60 per cent of employees hold only a primary school certificate (ANEMM 2000; AIMO 2010). The same percentage holds for employees among contractors and only 9 per cent had finished secondary school. While the supply of unskilled labour is in excess, contractors argue that there is considerable scarcity of mid-level managers, project directors, supervisors and head-masters for building, carpentry, metal work, electricity, welders and water pumps (Marrengula et al. 2012).

While the industrial weak performance reported here may in fact be associated with the low level of economic development in Mozambique, it is also the result of a persistent policy bias against vocational and technical education. In line with the objectives set for the Millennium Development Goals, the education strategy paper for the period 2006-11 reserved almost 50 per cent of the available education resource envelope for the expansion of primary education (Table 19). The share for secondary and higher education were estimated at 30 per cent. Adult education, which is meant to target most of the current entrants in the labour market, teachers, vocational and technical training, combined received an average of 5 per cent of the total projected education expenditures for the 2006-11 period.

Table 19: Distribution of the projected education expenditures, 2006-10

\begin{tabular}{lrrrrr}
\hline & 2006 & 2007 & 2008 & 2009 & \multicolumn{2}{c}{2010} \\
\hline Primary education & 49,9 & 48,8 & 48,8 & 48,8 & 49,4 \\
Secondary school educ.(1st cycle) & 11,9 & 11 & 11,7 & 13,1 & 13,9 \\
Secondary school educ.(2nd cycle) & 6,5 & 7,1 & 7,4 & 8,1 & 8,7 \\
Vocational and technical educ. & 4,1 & 3,8 & 3,8 & 4 & 4 \\
Teachers training & 0,4 & 0,8 & 1 & 0,7 & 0,7 \\
Adult education & 0,8 & 0,9 & 1 & 1,1 & 1,1 \\
Higher education & 19,1 & 20,2 & 19,7 & 17,7 & 16 \\
Culture & 0,9 & 1,1 & 1,1 & 1,1 & 1,1 \\
HIVIAIDS & 1 & 1,1 & 1,1 & 1,2 & 1,2 \\
Administration & 5,4 & 5,3 & 4,8 & 4,2 & 3,6 \\
Total & 100 & 100 & 100 & 100 & 100 \\
\hline
\end{tabular}

Source: MEC (2005).

The short-term effect of this policy can be spotted in Figure 14. Due to their secondary school background, at the Eduardo Mondlane University, the largest of all Mozambican universities, most university graduates are from the Faculty of Arts and Social Sciences. 
Figure 14: Percentage distribution of graduates at Eduardo Mondlane University (in \%)

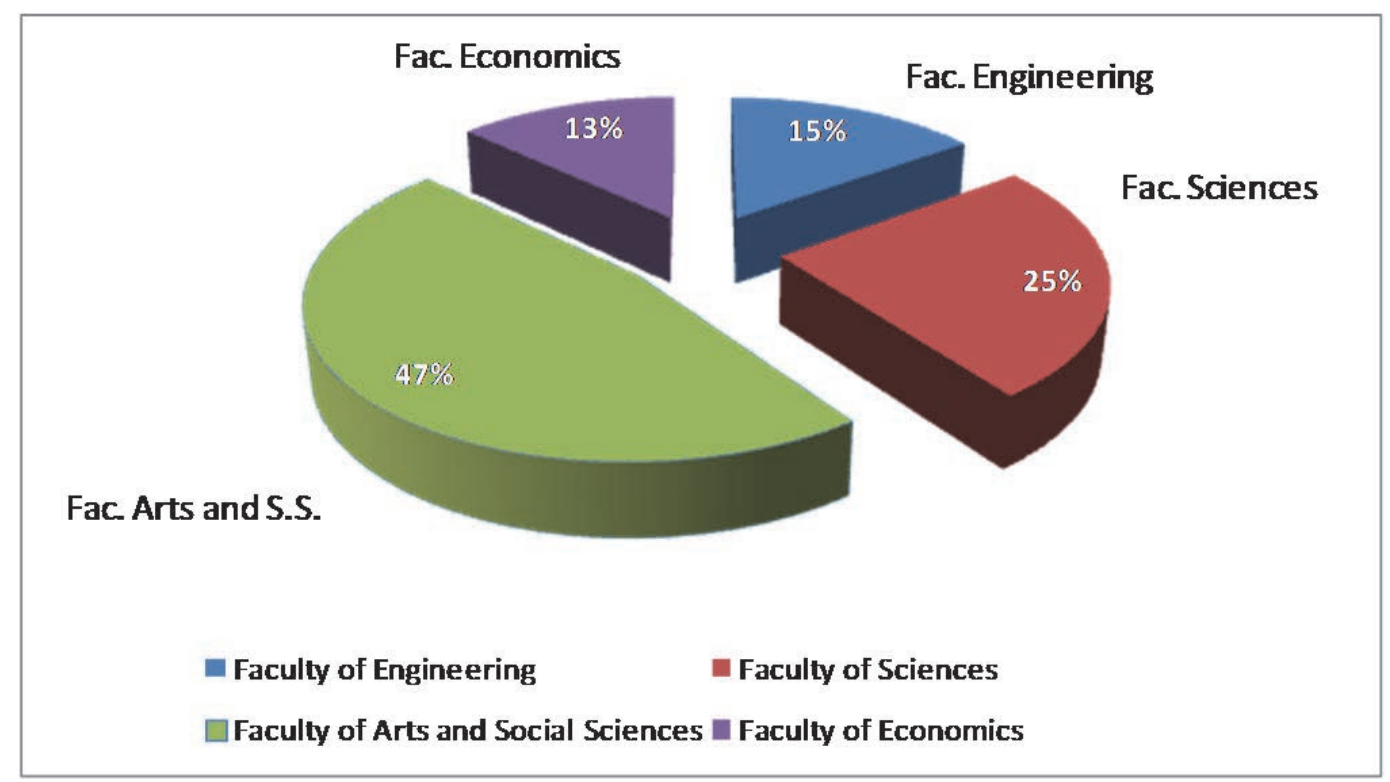

Source: UEM (2007).

While young graduates and government plans report unemployment as one of the main social issues, high growth industries claim that they are failing to employ the right people. AIMO (2010) found that local industries' needs ranged from general positions, such as administrative workers, accountants and budgeting officers, to specialized ones, such as certified welders, mechanical engineers and workplace safety and hygiene specialists. It is being hard for industries to find the appropriate and internationally certified technical skill in a labour market dominated by people without qualifications, holding secondary school grade or social science degrees.

In order to attract the private sector to the process of building a qualified labour force, the government enacted a new investment code prescribing fiscal incentives for those companies investing on training. So far, however, the results have been limited. Due to the relatively weak judicial system and constraints related to the flow of information regarding training opportunities for indigenous businesses, companies are reluctant to train their own manpower (AIMO 2010).

In order to remain productive, industrial firms are forced to allocate more resources than necessary in retraining new employees. Alternatively, they employ costly expatriates or retired personnel. In such an environment only few industries successfully sustain business relations with high-income local and overseas market segments.

For the domestic industries the final consequences of the relative scarcity of qualified manpower are: (i) reduced flow of investment partners; (ii) inability to access and explore highly remunerated projects; (iii) specializing the local industries on the low end of the market segment; and (iv) increased market power for those companies (few and foreign-owned) with the necessary capital for hiring employees worldwide. 


\subsection{Financial system}

Mozambique's financial system has made significant progress since the introduction of PRE in 1987. The number of banks went from three at the beginning of the PRES to 18 in March 2012. The country got its first stock exchange in 1999. The number of insurance and microfinance institutions has also expanded. As a result, financial savings, captured by the volume of term deposits tripled from 9.1 per cent as a percentage of broad money (M3) to 31 per cent in 2008 (Navalha 2009).

For local industries, this success did not improve access and the availability of funds, particularly for long-term investment (ANEMM 2000; AIMO 2010).

The liberalization of the financial sector has in fact increased demand for collateral and raised interest rates, alienating those companies who cannot comply. The local entrepreneurs, in particular industrialists are affected twice as a result. They cannot invest in long-term projects because they lack financial capacity to pay for project insurance and long-term credits are the scarcest input in the market. The poor access to finance for production purposes is grounded on the following factors discussed below.

Business environment constraints refer to the weaknesses associated with property rights protection and financial sector structural limitations. The judiciary system remains weak in the enforcement of financial transactions. Property rights bureaus operate below desirable level of efficiency and the risk management agencies are still in their early stages, having access to human capital among major limitations. They are also unable to generate the relevant information about the risk profile of customers and related property rights. Overall, their coverage is deficient.

The availability and access to the necessary project finance is constrained by: (i) banking sector market concentration; and (ii) low levels of financial savings in the face of high public sector demand, with deposits to credit ratio reported to be below the average for SSA (IMF 2010). Among 183 economies, Mozambique is 127 th on access to finance, behind Angola, Mauritius, Tanzania and South Africa, which is placed 2nd in SSA (World Bank 2011).

Recent Bank of Mozambique policy measures were meant to improve the state of economic conditions in Mozambique. In the last five years the reduction in the capital requirement ratio led to the emergence of new financial institutions, hence increasing financial inclusion. It also led to financial innovations, particularly within the microfinance segment, with indirect effects on interest rates and the degree of competition.

The challenge of a more targeted intervention with a view to support sustained growth of Mozambican entrepreneurs and long-term investment, however, still remains (ANNEM 2000; AIMO 2010). The gap between deposit and credit interest rate has diminished but it remains high by SSA standards. Recent interventions by the monetary authorities led to additional reductions, but it is unclear how long it will take to significantly improve the situation.

A recent study by the Bank of Mozambique (Banco de Moçambique 2007) reports limitations on the central bank transmission mechanism. There is a small correlation between the central bank rediscount rate and commercial banks interest rate. This is most likely the result of market concentration, associated with the limited degree of secondary market interactions and the possibility of profitable overseas banking businesses. The possibility of using other instruments, 
such as government bonds and the stock exchange would open space for improvements, but this still remains a long-term objective due to the low level of capital market development.

\subsection{Business management}

Management practices within the local companies are weak, reflecting historical factors: the massive post-independence exodus; the state intervention in the second half of the 1970s and mid-1980s; and the privatization of state assets in the context of a liberalized economy afterwards. The overall effects of colonialism and attempted socialism were the underdevelopment of indigenous capabilities, fractured logistics and limited market intelligence.

When a market-friendly approach surfaced, business management capacities were a scarce resource and continue to remain relatively weak now. Among the local entrepreneurs, financial management practices, accounting and corporate governance are generally poor, increasing the banks' perceived risks of lending to the local business community (Marrengula et al. 2012).

Changing this requires both short-term and long-term measures to support training of manpower. In line with this sentiment, the government has supported the emergence of mid-level and higher education institutions geared towards the study of business and management. Nonetheless, there are concerns about the competency of their graduates, partly due to the low level of investment on teachers.

\subsection{Technology}

Mozambique has not taken advantage of technological innovations worldwide. This is visible in the World Economic Forum technological performance indicator, where the country is ranked 116th in the world, below South Africa, Botswana, Namibia, Zambia and Lesotho (AIMO 2010; World Economic Forum 2010).

Mozambique's poor performance is a result of the following factors: (i) reduced degree of absorption of new technology associated with the lack of skills; (ii) low levels of innovation, (iii) weakness in protecting intellectual property rights; and (iv) reduced private sector investment in research and development, due to its relatively small-size and undercapitalization (ANEMM 2000; AIMO 2010).

Indeed, the government industrial strategies for the period from 1997 to 2012 flagged this issue, pointing out the technology gap as one of the main factors behind the indigenous companies' inability to compete. The strategy called for urgent measures, but in a recent survey, AIMO (2010) found that the situation has not changed despite the fact that the implementation period of the industrial policy and strategy paper is reaching its end. Over 62 per cent of the companies surveyed in the course of the AIMO 2010 study had not made major acquisitions of new technologies since the 1990s, their machinery was over 20 years old and they were finding it hard to maintain and replace spare parts (ANEMM 2000; AIMO 2010).

There are several reasons for the reported situation. Around 42 per cent of the surveyed companies complained about the lack of finance and the costs of acquiring new technology; 17 per cent reported their inability to access skilled labour as the main constraint; while the inability to compete in the market (14 per cent), lack of support services (11 per cent), market information gaps on new technologies ( 9 per cent) and import procedures constraints $(6$ per cent), constitute the remaining 
factors. Only one company reported to have had access to new technology due to its ties with foreign investors. It is this linkage that it is believed generally ensures ready access to new technologies and allows for constant upgrading and maintenance in a Mozambican context (AIMO 2010; Marrengula et al. 2012).

5

\section{Conclusion}

Mozambique post-independence industrial development background can be divided in two phases. The first 11 years of the socialist experiment came with strong state activism, a destructive war and a failed economy. This was indeed a lost decade for industrialization. The country failed to sustain and maximize the gains to industry that resulted from the colonial era active industrial policies. The country lost export markets and the industrial base. When it became a member of the World Bank and the IMF, the industrial sector was in a collapse state, with redundant workers, outdated equipment and frequent break downs.

The introduction of liberalization measures, starting in 1987, a new constitution in 1990 and a peace agreement in 1992, brought new economic opportunities and access to donor funds. This was indeed the beginning of the second phase, with a growing economy and the emergence of new industries. In the last 20 years the country average growth rate is estimated at 7 per cent.

Recent government industrial policy interventions follow a typical liberal approach, relying on the private sector to steer economic growth and the state with a hands-off stance until 2004 and a more pro-active role since 2005. On both of these sub-periods, the public sector role has been perceived as a provider of enabling an environment for the private sector, with drawbacks and advantages.

The main drawbacks were a hands-off approach from 1994 onwards and an oligopolistic approach worsened after 2005. The extreme liberal approach regarding the industrial sector from the government elected in the first multiparty elections in 1994, led to a significant deindustrialization of cashew nuts, food processing (tomato, fruit juices, milk products, wheat and other cereal products), textile, construction materials, chemical, metallurgical and equipment branches. At the same time, other processing branches were expanding, like beverages, grain milling, sugar, tobacco, cement, tyres.

At this stage, licensing procedures ensured that selected interests linked to the winner party conditioned the private investment on their representation in the social capital of the created companies. This tradition became acute and centralized to a limited number of interests after 2004 . At the same time, public companies or enterprises with public capital ensured management places for this oligopoly.

Two consequences derived from this approach: there was a marginalization of thousands of potential local entrepreneurs, among young people and others, from business opportunities in industry; manufacturing expansion lost momentum after 2004. The construction sector developed, but failed to create larger local companies to participate in the booming infrastructure phase. Although most of the sectors were growing, the economy became dominated by a profitable financial sector of banks and insurance companies, as well as large public natural monopolies and opportunistic large construction and commercial companies. 
On the advantages side, with the implementation of the first and the second industrial policy and strategy papers from 1997 and 2007 and other policy instruments, the country has moved to a new stage of pseudo-industrial development. It has managed to establish and run, with relative degree of success, some of the necessary institutions for sustaining existent industrial companies. These include: (i) the Beluluane export processing zone, hosting the Mozal smelter project and its suppliers; (ii) The Nacala special economic zone; (iii) the Institute for the Promotion of Micro, Small and Medium Enterprises (IPEME); (iv) the statute for micro, small and medium enterprises; (v) the district development fund; (vi) the Maluana technology park; and (vii) a one-stop electronic window for clearing imports.

Global players are investing billions of dollars for exploitation of mineral resources, including coal, gas, iron and gold. The reserves of identified coal and gas put Mozambique among the top potential world producers. There is also evidence of efforts to invest in developing the national standard and quality control framework as well as the country skill and entrepreneurship profile. The number of vocational schools increased from 36 in 2009 to 44 in 2012.

Liberalization, however, exposed the domestic industry to the winds of globalization. To be successful a number of challenges need to be addressed, including: (i) skills development; (ii) improving the access to financial resources; (iii) improving the access to technology; (iv) improving the access to cheaper and more reliable electricity and water; (v) fine tune tax policy; (vii) improve regulations and practices for both imports and exports.

\section{References}

ACIS (no date). 'Kenmare: Areias Pesadas de Moma'. Available at: http://acismoz.com/acisofala/UserFiles/file/Investor\%20Profile/Kenmare.pdf (accessed on 6 February 2014).

AIMO (2010). 'Competitividade Industrial de Moçambique'. Maputo: Associação Industrial de Moçambique. Maputo: AIMO.

Andersson, P.-Å. (2002). 'Impacto dos Megaprojectos na Economia Moçambicana' . In A Economia Mosambicana Contemporanea: Ensaios. Maputo: Gabinete de Estudos, Ministério do Plano e Finanças.

Andersson, P.-A., and Sjö, B. (2002). 'O Sucesso Moçambicano no Controlo da Inflação durante a Transição para uma Economia de Mercado'. In A Economia Moçambicana Contemporanea: Ensaios. Maputo: Gabinete de Estudos, Ministério do Plano e Finanças.

Associação Nacional das Empresas Metalúrgicas e Metalomecânicas (ANEMM) (2000). 'Sectores de Destino da Produção da Metalurgia e Electromecânica: Moçambique'. Vol. II. Lisboa: ANEMM.

Banco de Moçambique (2007). 'Custos de Intermediação Financeira versus Rentabilidade das Instituições Financeiras’. Relatório ao XXXII Conselho Consultivo do Banco de Moçambique.

Byiers, B., and Rand, J. (2006). 'Enterprise Development in Mozambique: Results Based on Manufacturing Surveys Conducted in 2002 and 2006'. Discussion Papers No. 33 E. Maputo: DNEAP-MPD. 
Brum, J.M. (1976). 'Manufacturing Industries in Mozambique: Some Aspects'. Maputo: Universidade Eduardo Mondlane, School of Economics.

Campbell White, O., and Bhatia, A. (1998). Privatization in Africa. Washington, DC: World Bank.

Castel-Branco, C.N. (2002). 'Investigation into the Political Economy of Industrial Policy: the Case of Mozambique'. PhD Thesis. London: School of Oriental and African Studies, University of London.

Castel-Branco, C.N. (2003). 'Indústria e Industrialização em Moçambique: Análise da Situação Actual e Linhas Estratégicas de Desenvolvimento'. Available at: http://www.iese.ac.mz/lib/cncb/AI\%202003c\%20QUADER_.PDF

Castel-Branco, C.N. (2008). 'Alguns Pontos que Gostaria de ver Abordados no Discurso do Presidente sobre o Estado da Nação. Comentários e Opiniões’. IESE, Maputo. Available at: http://www.iese.ac.mz/lib/publication/outras/Pontos_para_a_entrevista_sobre_estado_da_n acao.pdf (accessed on 10 February 2014).

Castel-Branco, C.N. (2010). 'Economia Extractiva e Desafios de Industrialização em Moçambique'. In Economia Extractiva e Desafios de Industrialização em Moçambique. Maputo: IESE.

Castel-Branco, N.C., Cramer, C., and Hailu, D. (2001). 'Privatization and Economic Strategy in Mozambique'. WIDER Discussion Paper 6. Helsinki: UNU-WIDER.

CIP (2013). 'Pande Temane Gas Exports to South Africa: First Major Extractive Sector Projects Fails Mozambique'. Maputo: Centro de Integridade Publica. Available at:http://www.cip.org.mz/cipdoc/274_Pande\%20Temana\%20Gas\%20exports\%20to\%20Sout h\%20A frica\%20by\%20Sasol.pdf (accessed on 6 February 2014).

Cruz, A. (1994). 'Transformações da Indústria em Moçambique'. Tese de Licenciatura. Maputo: Universidade Eduardo Mondlane, Faculdade de Economia.

DNE-CNP (1985). 'Informação Estatística 1975-1984'. Maputo: Direcção Nacional de Estatística, Comissão Nacional do Plano.

DSPIE (1962). 'Comércio Externo 1962'. Lourenço Marques: Direcção dos Serviços Provinciais de Informação Estatística, Moçambique.

DSPIE (1973). 'Comércio Externo 1973’. Lourenço Marques: Direcção dos Serviços Provinciais de Informação Estatística, Moçambique.

EBSCO (2007). 'Brazil's CVRD to Start Moatize Construction Later This Year'. Available at: http://connection.ebscohost.com/c/articles/26409791/brazils-cvrd-start-moatizeconstruction-later-this-year (accessed on 6 February 2014).

Econex (2009). 'The Cost of Doing Business in Mozambique relative to other SADC Countries'. Research Note 10, by Johann van Eden.

EDM (2010). 'Sumário Estatístico/Statistical Summary'. Maputo: Electricidade de Moçambique.

Foreign Investment Advisory Service (FIAS) (2006). 'Tourism Sector in Mozambique: A Value Chain Analysis'. Vol. 1, Washington, DC: FIAS, IFC - World Bank Group.

FIAS (2008). 'Special Economic Zones: Performance, Lessons Learned, and Implications for Zone Development'. Washington, DC: World Bank. Available at: 
https://www.wbginvestmentclimate.org/toolkits/investment-generation-toolkit/upload/SEZReport-April-2008.pdf

Frelimo (1977). 'Directivas Económicas e Sociais'. Maputo: Colecção III Congresso.

Frelimo (1983). 'Directivas Económicas e Sociais’. Maputo: Colecção IV Congresso.

Governo de Moçambique (GOM) (2005). 'Plano de Acção para a Redução da Pobreza Absoluta 2006-2009’. Maputo: GOM.

GOM (2012). 'Balanço de Meio-Termo do Programa Quinquenal do Governo 2010-2014: 2012'. Mimeo. Maputo: GOM.

ICA (2003). 'Mozambique Industrial Performance and Investment Climate 2003'. Investment Climate Assessment, Washington, DC: Regional Program for Enterprise Development (RPED), Africa Private Sector Group, IFC, World Bank, August, Written by: Nasir, J., Barros, G. de, Wagle, D., Shah, M.K., Leechor, C., Srivastava, P., Harding, A., and Ramachandran, V.

ICA (2009). 'Mozambique Investment Climate Assessment 2009'. Investment Climate Assessment, Washington, DC: Regional Program for Enterprise Development (RPED), Africa Finance and Private Sector (AFTFP), World Bank, October, Written by: Reis, J.G., Bouri, M., Maimbo, S.M., and Quijada, C.

International Monetary Fund (IMF) (2009). 'Regional Economic Outlook: Sub-Saharan Africa, April 2009'. World Economic and Financial Surveys. Washington, DC: IMF.

IMF (2010). 'Republic of Mozambique: Financial Sector Assessment Program- Financial System Stability Assessment'. IMF Country Report No. 10/12. Washington, DC: International Monetary Fund.

Im-Mining (2013). 'Global Coal Review'. Available at: http://www.immining.com/2013/08/01/global-coal-review/ (accessed on 6 February 2014).

Instituto Nacional de Estatística (INE) (1993-2011). 'Anuário Estatístico 1992'. (1993-2010), Maputo: INE.

INE (2009-11). 'Inquérito Anual às Empresas 2006, Principais Resultados'. (2007-09) Maputo: Instituto Nacional de Estatística.

INE (2010). 'Projecções anuais da população total, urbana e rural: 2007-2040'. Maputo: Instituto Nacional de Estatística.

INE (2012). 'Série de Contas Nacionais 1991-2011'. Instituto Nacional de Estatística. Available at: www.ine.gov.mz (accessed 2012).

Jones, E.S. (2006). 'Growth Accounting for Mozambique 1980-2004'. Discussion Paper No. 22. Maputo: DNEAP-MPDE.

Jones, E.S., and Tarp, F. (2012). 'Jobs and Welfare in Mozambique - Country Case Study for the 2013 World Development Report'. Available at: http://siteresources.world $\neg$ bank $\neg$.org/EXTNWDR2013/Resources/8258024-1320950747192/8260293-1320956712276/82610911348683883703/WDR2013_bp_Jobs_and_Welfare_in_Mozambique.pdf

Krause, M., and Kaufmann, F. (2011). 'Industrial Policy in Mozambique'. Discussion Paper 10/2011. Bonn: German Development Institute. 
Leite, J.P. (1989). 'Pacte Colonial et Industrialization: Du Colonialism Portugais aux Réseaux Informell de Sujétion Marchande - 1930/1974'. PhD Thesis, Vols. I and II. Paris: École des Hautes Études en Sciences Sociales.

Marrengula, C., Nhabinde, V., and Ubisse, A. (2012). 'The Challenges and the Way Forward for the Construction Industry in Mozambique'. Report to the International Growth Centre in Mozambique.

McMillan, M., Rodrik, D., and Welch, K.H. (2002). 'When Economic Reform Goes Wrong: Cashews in Mozambique'. NBER Working Paper 9117. Cambridge, MA: NBER:

Ministério da Indústria e Comércio (MIC) (1997). 'Politica e Estratégia Industrial 1997'. Maputo: MIC.

Ministério da Indústria e Comércio (MIC) (2007). 'Politica e Estratégia Industrial 2007'. Maputo: MIC.

Ministério da Educação e Cultura (MEC) (2005). 'Estratégia da Educação e Cultura 2006-11'. Ministério da Educação e Cultura, Moçambique. Available at: www.portaldogoverno.gov.mz (accessed on 30 April 2010).

MITRAB (2006). 'Estratégia de Emprego e Formação Profissional 2006-2015’. Maputo: Ministerio do Trabalho, Instituto Nacional de Emprego e Formação Profissional, Moçambique.

Ministério das Colónias em Moçambique (1928). 'Código do Trabalho dos Indígenas'. Decreto no. 16199, 6 Dez.

Presidência do Conselho em Moçambique (1961). 'Integração Económica Nacional'. Decreto-Lei no. 44016, 8 Nov.

Mondlane, E.C. (1976). 'Lutar por Moçambique'. Lisboa: Sá da Costa, 1977, $3^{a}$ edição.

Ministério da Planificação e Desenvolvimento (MPD) (2010). 'Pobreza e Bem-estar em Moçambique: Terceira Avaliação Nacional'. Maputo: Direcção Nacional de Estudos e Análise de Políticas (DNEAP) e Universidade de Copenhaga (KU), Ministry of Planning and Development (MPD), Out.

MPD (2012a). 'Informações do Governo à Assembleia da República: Intervenção de S. Excia Aiuba Cuereneia, Ministro da Planificação e Desenvolvimento'. Maputo, Moçambique, 11 Abr., Mimeo,

MPD (2012b). 'Mega-projectos: Fim dos Benefícios'. Available at: http: / / www.rm.co.mz/index.php?option $=$ com_content\&view $=$ article\&id $=3795: \mathrm{mega}-$ projectos-fim-dos-beneficios\&catid=1:ultimas\&Itemid=50, 8 Ago (accessed 6 February 2014).

MPD, MF and BM (2011). 'Reflexão sobre a contribuição dos Projectos de Grande Dimensão na economia de Moçambique'. Maputo, Mimeo.

Navalha, F. (2009). 'Desafios de Financiamento às PME`s em Ambiente de Crise Financeira'. Maputo.

Rand, J. and Tarp, F. (2013). 'Inquérito às Indústrias Manufactureiras (IIM 2012): Relatório Descritivo'. Maputo: DNEAP-MPD; Copenhaga: KU.

RPED (1999). 'Structure and Performance of Manufacturing in Mozambique'. RPED Paper No. 107. Washington, DC: World Bank. 
SourceWatch (2013a). 'Mozambique and Coal'. Available at: http://www.sourcewatch.org/index.php/Mozambique_and_coal (accessed on 6 February 2014).

SourceWatch (2013b). 'Benga Coal Mine'. Available at: http://www.sourcewatch.org/index.php/Benga_coal (accessed on 6 February 2014).

SourceWatch (2013c). 'Rio Tinto Coal Mozambique'. Available at: http://www.sourcewatch.org/index.php/Rio_Tinto_Coal_Mozambique (accessed on 6 February 2014).

SPEED (2013). 'Pagamento de Impostos em Moçambique'. Maputo: Projecto SPEED, USAID Mozambique, Autora: Remane, N.V.

Sulemane, J. (2002). 'Dados Básicos da Economia Moçambicana'. In A Economia Moçambicana Contemporanea: Ensaios. Maputo: Gabinete de Estudos, Ministério do Plano e Finanças.

TMSA (2011). 'Mozambique Benga Coking Coal Exports in 2012'. Available at: http://www.trademarksa.org/news/mozambique-benga-coking-coal-exports-2012 (accessed on 6 February 2014).

Universidade Eduardo Mondlane (UEM) (1983a). 'História de Moçambique, Volume II: Agressão Imperialista (1886/1930)'. Maputo: Faculdade de Letras, University Eduardo Mondlane.

UEM (1983b). 'História de Moçambique, Volume III: Moçambique no Auge do Colonialismo (1930/1961)'. Maputo: Faculdade de Letras, Universidade Eduardo Mondlane.

UEM (2007). 'Distribuição dos Estudantes Graduados da UEM, pelas Faculdades'. Mimeo. Maputo: UEM.

UTRE (no date). 'Privatization in Mozambique: Country Fact Sheet'. Available at: http://www.fdi.net/documents/WorldBank/databases/plink/factsheets/mozambique.htm (accessed on 4 February 2014).

Warren, A.N. (2010). 'Uncovering Trends in the Accumulation of Technological Capabilities and Skills in the Mozambican Manufacturing Sector'. Oxford Development Studies, 38(2), 171-98.

Wield, D. (1977). 'Some Characteristics of the Mozambican Economy, Particularly Relating to Industrialization'. Working Paper, Centro de Estudos Africanos. Maputo: UEM.

World Bank (2011-2014). 'Doing Business 2011'. (2012-2014), Washington, DC: World Bank.

World Economic Forum (2010). 'Global Information Technology Report 2009-2010'.

Wuyts, M. (1980). 'Economia Política do Colonialismo'. Estudos Moçambicanos (1). Maputo: CEA, UEM.

Wuyts, M. (1983). 'A Organização das Finanças e o Desenvolvimento Económico em Moçambique: Do Sistema Capitalista Colonial ao Desenvolvimento Socialista'. Texto de Apoio no.15, Centro de Estudos Africanos. Maputo: UEM. 